\title{
Application of the HELP Model for Landfill Design in Arid Areas: Case Study Babylon Governorate, Iraq
}

\author{
Ali Chabuk ${ }^{1,2}$, Nadhir Al-Ansari ${ }^{1}$, Jan Laue ${ }^{1}$, Karwan Alkaradaghi ${ }^{1,3}$, Hussain Musa Hussain ${ }^{4,5}$ and Sven \\ Knutsson $^{1}$ \\ 1. Department of Civil Environmental and Natural Resources Engineering, Lulea University of Technology, Lulea 97187, Sweden \\ 2. Department of Environment Engineering, College of Engineering, University of Babylon, Babylon 51001, Iraq \\ 3. Kurdistan Institution for Strategic Studies and Scientific Research, Sulaimaniyah 460013, Iraq \\ 4. Remote Sensing Center, University of Kufa, Kufa 51001, Iraq \\ 5. Department of Geology, Faculty of Science, University of Kufa, Najaf 54003, Iraq
}

\begin{abstract}
The landfill design is necessary to be implemented in various regions to protect public human health and the factors of environment. The suggested design of landfill was performed in the arid areas, where that Babylon Governorate, Iraq was selected as a case study. Babylon Governorate is located in the middle of Iraq. The suggested design for the selected sites for landfill in the arid areas was consisted of the base liner and final cover systems. The HELP 3.95D model was applied on both systems to check if there is any leakage by leachate from the suggested soil layers of landfill base on the water balance in Babylon Governorate for the years 2005-2016. The suggested design of final cover system was implemented based on weather parameters in the arid areas through storing water that coming from the surface within upper layers that have fine particles and over the top barrier without leakage into the waste body, thereby preventing leachate generation. This is allowing to the stored water to evaporate from the surface of soil or transpire through vegetation due to the high temperature during the most months in the study area. The results showed there was no percolation of leachate through the base liner system. The design of final cover system was acted to reduce the runoff on the surface and increase the actual evaporation.
\end{abstract}

Key words: Landfill design, arid areas, soil layers, solid waste, HELP model.

\section{Introduction}

Landfill is considered a common systematic and economic technique to manage the MSW (municipal solid waste) disposal in most countries, especially developing countries even though when other methods are for waste management such as recycling, reuse, burning and burial are used [1-5]. MSW consists of organic, commercial, industrial, institutional and construction wastes [6].

Inefficient management of landfills gives negative impacts on the human health and environmental factors when implemented the landfills in several countries such as pollution of groundwater and surface water by

Corresponding author: Nadhir A. Al-Ansari, professor, research fields: water resources and environment. leachate, gas emissions to atmosphere and other $[5,7$, 8]. The systematic design of landfill consists of two systems are the base liner system and the final cover system.

The aim of using the base liner system in modern landfills is to control contamination resulting from landfill on environmental factors, where that the leachate generated from landfills represents the main threat to groundwater and soil. The main sources of leachate are rainfall and the water that comes from the waste itself. In modern landfills, the base liner system is constructed to form a barrier between the waste and the ground. In addition, this system works to drain the leachate to treatment facilities using the leachate collection system [9].

The final cover system works to isolate the waste 
mass from surrounding environment by putting the suitable layers of the final cover system for the landfill on the waste surface. The layers of the final cover system work to avert water infiltration into the waste body, consequently, reducing the generation of leachate downward in the landfill. Furthermore, the final cover system is contributed to reducing the surface erosion by improving the drainage into the layers of system regularly [10].

Selecting sites for landfill should adopt the most significant criteria for the study area. These criteria are different from area to another depending on the existing factors and conditions.

Babylon Governorate locates in the arid-hot area, and its groundwater depth is shallow ranging from $0.423 \mathrm{~m}$ to $15.97 \mathrm{~m}$ below the ground-level [11]. Therefore, the special conditions in Babylon Governorate should be taken into consideration when selecting the criteria for landfills siting, also when adopting the suitable suggested design for the base liner and the final cover systems in the landfill to protect human health and to conserve the environmental parameters from contamination (air, soil and water).

The hydrologic evaluation of landfill performance (HELP 3.95D) model was applied to check the proposed design for the selected sites for landfills in the districts of Babylon governorate. The data of soil layers' design with the weather data parameters were combined in this model. The HELP model was applied to estimate the water balance for the base liner and the final cover systems in the landfill. In the HELP model, the amount of leachate percolated was calculated through the soil layers. In addition, the amount of runoff and actual evapotranspiration that result from rainfall was estimated when the suggested layers were used for the final cover system of landfill [12-14]. In the literature reviews, several previous studies used the different versions of the HELP model to estimate the leachate within the landfill sites (e.g., [4, 15-19]).

The main objective of this study is to select an appropriate design for the base liner system and the final cover system for the selected sites in Babylon Governorate, which is located in the arid areas. The layers of the base liner system should be designed perfectly to prevent the groundwater pollution by leachate percolating in these sites because the groundwater depth in Babylon Governorate is very shallow. The suggested final cover system should be designed to achieve its main purposes through reducing the surface runoff, increasing the actual evapotranspiration and decreasing the water infiltration into the waste body which helping reduce the leachate generation. Then, apply a suitable model on the suggested design for the selected landfill sites in the governorate to check the suitability and efficiency of this design for the study areas.

\subsection{Previous Studies for Landfill Design}

In the literatures, many previous studies were issued concerning the environmental guidelines and recommendations for landfills' design in various countries and in different regions, including the base liner system and the final cover system. Table 1 is a summary of previous required designs for the base liner system for the landfills in different countries and regions, while Table 2 displays the summary of designs' requirements and the characteristics of the layers for the final cover system for the landfills.

\subsection{Study Area (Babylon Governorate, Iraq)}

Babylon Governorate is situated in the middle of Iraq about $100 \mathrm{~km}$ to the south of Baghdad (the capital Iraqi), and it locates between latitudes $32^{\circ} 5^{\prime} 41^{\prime \prime} \mathrm{N}$ and $33^{\circ} 7^{\prime} 36^{\prime \prime} \mathrm{N}$, and longitudes $44^{\circ} 2^{\prime} 43^{\prime \prime} \mathrm{E}$ and $45^{\circ} 12^{\prime} 11^{\prime \prime} \mathrm{E}$ (Fig. 1). Babylon Governorate includes the Babil city which considered the most famous city of the ancient world and is part of "Cradle of Civilizations". The Babil city was built 4,100 years ago; it represented the power center of an expansive and influential empire $[26,27]$. Babylon Governorate has a strategic location through connecting the north and south governorates of Iraq [28]. 
Table 1 Summarize of previous designs for the base liner system for landfills.

\begin{tabular}{|c|c|c|c|c|c|}
\hline $\mathrm{N}$ & Items & Thickness & No. & Items & Thickness \\
\hline \multicolumn{3}{|c|}{ Victoria, Australia [20] } & \multicolumn{3}{|c|}{ Devon, Gauteng, South Africa (Subtropical latitude) [21] } \\
\hline 1 & Sub-base. & $30 \mathrm{~cm}$ & 1 & Subgrade. & - \\
\hline 2 & $\begin{array}{l}\text { Compacted clay layer with hydraulic } \\
\text { conductivity of } \leq 1.0 \mathrm{E}-9 \mathrm{~m} / \mathrm{s} \text {. }\end{array}$ & $1 \mathrm{~m}$ & 2 & $\begin{array}{l}\text { Compacted clay layer with four lifts, and its } \\
\text { hydraulic conductivity is } \leq 1.0 \mathrm{E}-9 \mathrm{~m} / \mathrm{s} \text {. }\end{array}$ & $60 \mathrm{~cm}$ \\
\hline 3 & A geomembrane liner (HDPE). & $\geq 1.5 \mathrm{~mm}$ & 3 & A geomembrane liner (HDPE). & $\geq 1.5 \mathrm{~mm}$ \\
\hline 4 & Protection non-woven geotextiles. & & 4 & $\begin{array}{l}\text { Protection layer (silty sand) or non-wave } \\
\text { geotextile as a protection layer. }\end{array}$ & $10 \mathrm{~cm}$ \\
\hline 5 & $\begin{array}{l}\text { Drainage layer (gravel) with hydraulic } \\
\text { conductivity of } \geq 1.0 \mathrm{E}-3 \mathrm{~m} / \mathrm{s} \text {, and leachate } \\
\text { collection pipes with diameter of }(15-20) \mathrm{cm} \text {. }\end{array}$ & $30 \mathrm{~cm}$ & 5 & $\begin{array}{l}\text { Leachate collection layer with hydraulic } \\
\text { conductivity of } \geq 1.0 \mathrm{E}-3 \mathrm{~m} / \mathrm{s} \text {, and leachate } \\
\text { collection pipes. }\end{array}$ & $\geq 15 \mathrm{~cm}$ \\
\hline 6 & Non-woven geotextiles filter layer. & - & 6 & Non-woven geotextiles filter layer. & - \\
\hline \multicolumn{3}{|c|}{ Kuwait (Arabic Gulf (arid area)) [22] } & \multicolumn{3}{|c|}{ Makkah, Saudi Arabia (Hot desert climate) [23] } \\
\hline 1 & \multicolumn{2}{|c|}{$\begin{array}{l}\text { Subgrade (compacted native soil) with hydraulic } \\
\text { conductivity of } \leq 1.0 \mathrm{E}-7 \mathrm{~cm} / \mathrm{s} \text {. }\end{array}$} & 1 & \multicolumn{2}{|c|}{$\begin{array}{l}\text { The base layer consists of compacted original } \\
\text { material to depth of } 1 \mathrm{~m} \text { above the water table. }\end{array}$} \\
\hline 2 & \multicolumn{2}{|c|}{$\begin{array}{l}\text { High compacted barrier layer with four lifts, and } 90 \mathrm{~cm} \\
\text { its hydraulic conductivity is } 1.0 \mathrm{E}-6 \mathrm{~cm} / \mathrm{s} \text {. }\end{array}$} & 2 & The compacted cushion layer (clean sand). & $30 \mathrm{~cm}$ \\
\hline 3 & \multicolumn{2}{|c|}{$\begin{array}{l}\text { Drainage layer contains coarse material (gravel } 30 \mathrm{~cm} \\
\text { or sand)/leachate collection pipes. }\end{array}$} & 3 & Geomembrane liner (HDPE). & $2.5 \mathrm{~mm}$ \\
\hline $\begin{array}{l}4 \\
5\end{array}$ & \multicolumn{2}{|l|}{$\begin{array}{l}\text { Non-wave geotextile filter layer. } \\
\text { Protective layer. }\end{array}$} & 4 & $\begin{array}{l}\text { Leachate collection system (gravel), and } \\
\text { leachate collection pipes. }\end{array}$ & $30 \mathrm{~cm}$ \\
\hline \multicolumn{3}{|c|}{ Ireland (Cold region) [24] } & \multicolumn{3}{|c|}{ British Columbia, Canada [25] (applying in arid \& non-arid areas) } \\
\hline 1 & Subgrade. & - & 1 & Subgrade (native soil or bedrock). & - \\
\hline 2 & $\begin{array}{l}\text { Compacted clay layer with four lifts, and its } \\
\text { hydraulic conductivity is } \leq 1.0 \mathrm{E}-9 \mathrm{~m} / \mathrm{s} \text {. }\end{array}$ & $\geq 1 \mathrm{~m}$ & 2 & $\begin{array}{l}\text { Compacted barrier layer (silty clay) and its } \\
\text { hydraulic conductivity is } \leq 1.0 \mathrm{E}-7 \mathrm{~cm} / \mathrm{s} \text {. }\end{array}$ & $75 \mathrm{~cm}$ \\
\hline 3 & Geomembrane liner (HDPE). & $>2 \mathrm{~mm}$ & 3 & Geomembrane liner (HDPE). & $1.5 \mathrm{~mm}$ \\
\hline 4 & $\begin{array}{l}\text { conductivity of } \geq 1.0 \mathrm{E}-3 \mathrm{~m} / \mathrm{s} \text {, and leachate } \\
\text { collection pipes with diameter of } 20 \mathrm{~cm} .\end{array}$ & $\geq 50$ & 4 & Non-wave geotextile protection layer. & - \\
\hline \multirow[t]{2}{*}{5} & \multirow[t]{2}{*}{ Protection layer. } & \multirow[t]{2}{*}{-} & 5 & $\begin{array}{l}\text { Leachate collection layer (gravel), and } \\
\text { leachate collection pipes. }\end{array}$ & $30 \mathrm{~cm}$ \\
\hline & & & 6 & Non-wave geotextile filter layer. & - \\
\hline
\end{tabular}

Table 2 Summarize of previous designs for the final cover system for landfill.

\begin{tabular}{|c|c|c|c|c|c|}
\hline $\mathrm{N}$ & Items & Thickness & No. & Items & Thickness \\
\hline \multicolumn{3}{|c|}{ Victoria, Australia [20] } & \multicolumn{3}{|c|}{ Devon, Gauteng, South Africa (subtropical latitude) [21] } \\
\hline 1 & Foundation layer. & $30 \mathrm{~cm}$ & 1 & Foundation and gas collection layer. & $15 \mathrm{~cm}$ \\
\hline \multirow{2}{*}{2} & \multirow{2}{*}{$\begin{array}{l}\text { High compacted clay layer (barrier soil) with } \\
\text { hydraulic conductivity of } \leq 1.0 \mathrm{E}-9 \mathrm{~m} / \mathrm{s} \text {. }\end{array}$} & \multirow{2}{*}{$<60 \mathrm{~cm}$} & 2 & Non-wave geotextile filter layer. & - \\
\hline & & & 3 & Compacted barrier layer with three lifts. & $45 \mathrm{~cm}$ \\
\hline 3 & Sub-soil layer. & $1 \mathrm{~m}$ & & & \\
\hline 4 & Topsoil layer. & $20 \mathrm{~cm}$ & 4 & Topsoil layer. & $20 \mathrm{~cm}$ \\
\hline \multicolumn{3}{|c|}{ Kuwait (Arabic Gulf (arid area)) [22] } & \multicolumn{3}{|c|}{ Makkah, Saudi Arabia (Hot desert climate) [23] } \\
\hline 1 & $\begin{array}{l}\text { Foundation and gas collection layer (compacted } \\
\text { natural soil). }\end{array}$ & $30 \mathrm{~cm}$ & 1 & Foundation cover layer of sand. & $30 \mathrm{~cm}$ \\
\hline 2 & $\begin{array}{l}\text { Compacted top barrier soil with three lifts, and } \\
\text { its hydraulic conductivity is } \leq 1.0 \mathrm{E}-5 \mathrm{~cm} / \mathrm{s} \text {. }\end{array}$ & $60 \mathrm{~cm}$ & 2 & $\begin{array}{l}\text { The cushion layer of moderately compacted } \\
\text { sand. }\end{array}$ & $30 \mathrm{~cm}$ \\
\hline 3 & Drainage layer. & $30 \mathrm{~cm}$ & 3 & $\begin{array}{l}\text { The synthetic clay liner (GCL) consists of } \\
\text { bentonite (six mm). The GCL layer is } \\
\text { positioned between two strong and thin layers } \\
\text { of the unwoven geotextile as a sandwich. }\end{array}$ & - \\
\hline 4 & Topsoil layer (mixture of silt and natural gravel). & $30 \mathrm{~cm}$ & 4 & $\begin{array}{l}\text { Topsoil layer with surface slope between } \\
3-5 \% \text {. }\end{array}$ & $20 \mathrm{~cm}$ \\
\hline
\end{tabular}


(Table 2 continued)

\begin{tabular}{|c|c|c|c|c|c|}
\hline $\mathrm{Nc}$ & Items & Thickness & No. & Items & Thickness \\
\hline \multicolumn{3}{|c|}{ Ireland (cold region) $[24]$} & \multicolumn{3}{|c|}{ British Columbia, Canada [25] (applying in arid \& non-arid areas) } \\
\hline 1 & $\begin{array}{l}\text { Foundation and gas collection layer (optional) } \\
\text { with hydraulic conductivity of } \geq 1.0 \mathrm{E}-3 \mathrm{~m} / \mathrm{s} \text {. }\end{array}$ & $\geq 30 \mathrm{~cm}$ & 1 & \multicolumn{2}{|c|}{$\begin{array}{l}\text { Compacted barrier with hydraulic conductivity } 60 \mathrm{~cm} \\
\text { of } \leq 1.0 \mathrm{E}-7 \mathrm{~cm} / \mathrm{s} \text {. }\end{array}$} \\
\hline 2 & $\begin{array}{l}\text { Compacted barrier layer with three lifts (each lift } \\
\text { of } 20 \mathrm{~cm} \text { ), and hydraulic conductivity is } \leq 1.0 \mathrm{E}-9 \\
\mathrm{~m} / \mathrm{s} \text {. }\end{array}$ & $60 \mathrm{~cm}$ & 2 & A geomembrane liner (HDPE). & $1.5 \mathrm{~mm}$ \\
\hline 3 & $\begin{array}{l}\text { Drainage layer (gravel) with hydraulic } \\
\text { conductivity of } \geq 1.0 \mathrm{E}-3 \mathrm{~m} / \mathrm{s} \text {. }\end{array}$ & $50 \mathrm{~cm}$ & 3 & Non-wave geotextile filter layer. & - \\
\hline 4 & Sub-soil layer. & $\geq 1 \mathrm{~m}$ & 4 & Sub-soil (support vegetation) layer. & $45 \mathrm{~cm}$ \\
\hline 5 & Topsoil layer of uniform soil. & $15-30 \mathrm{~cm}$ & 5 & Topsoil layer. & $15 \mathrm{~cm}$ \\
\hline
\end{tabular}

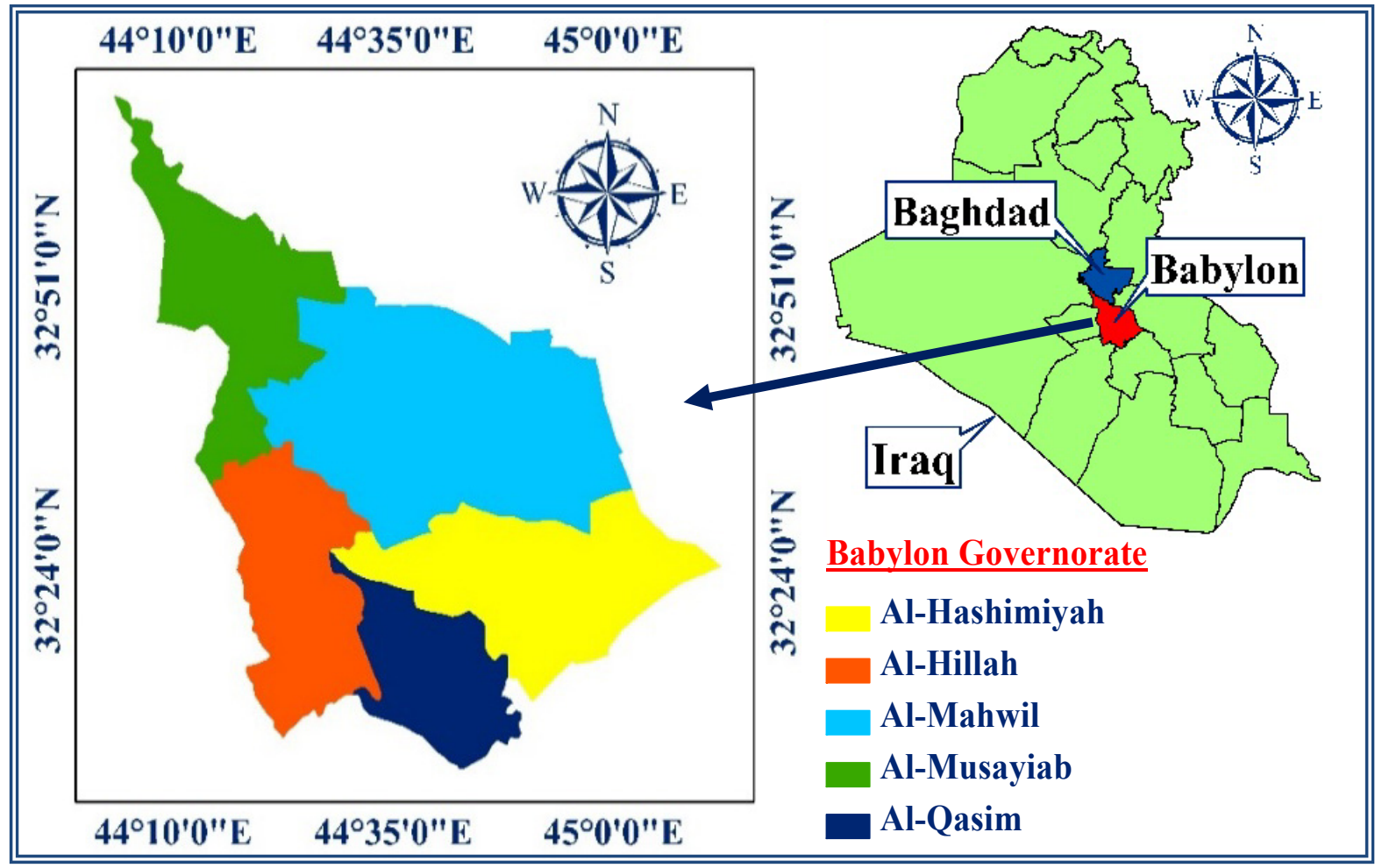

Fig. 1 Babylon Governorate, Iraq.

Babylon Governorate covers an area of $5,337 \mathrm{~km}^{2}$, including cities of Babylon Governorate. Babylon Governorate had a population of approximately $2,220,000$ inhabitants up to 2017 distributed throughout five major cities, referred to as districts or (Qadhaas) [29]. These districts are Al-Hillah, Al-Hashimiyah, Al-Musayiab, Al-Mahawil and Al-Qasim.

\subsection{Climate}

The climate of Iraq is divided mainly into three types. These are: continental, subtropical semi-arid and
Mediterranean [30]. According to FAO [31], Iraq is divided into four zones of agro-ecological which are [32]:

(a) The arid and semi-arid zones with a Mediterranean climate which covered mainly the governorates in northern parts of Iraq.

(b) The desert zone is extended from north of Baghdad to the borders of Saudi Arabian and Jordan, where the climate in this zone is distinguished by extreme temperatures in summer and the annual rainfall is less than $200 \mathrm{~mm}$.

(c) Steppes zone is located between the 
Mediterranean and desert zones, where that the annual rainfall in the cold winter is between $200-400 \mathrm{~mm}$ and the temperatures in summer are very hot.

(d) The irrigation area zone is located between the rivers of Tigris and Euphrates and extended from the north of Baghdad to the south in Basra.

The rainfall takes place during winter in most parts of Iraq (from December to February), while in mountains from November to April. The annual quantity of rainfall from the south and southwest to the north ranges from less than $100 \mathrm{~mm}$ to more than 1,000 $\mathrm{mm}$. The mean daily temperature is $16^{\circ} \mathrm{C}$ and at night, the temperature drops to $2{ }^{\circ} \mathrm{C}$. During the Summer, the climate is hot to so hot and dry (without rainfall), where the daily temperature during the hottest months July and August reaches over $43{ }^{\circ} \mathrm{C}$ in the shade and decreases to $26^{\circ} \mathrm{C}$ at night [30].

Babylon Governorate is located in the arid region in fertile land between the Tigris and Euphrates rivers [32, 33]. The winter season is usually rainy and cold, with about 6.8 hours/day of sunshine. The mean daily temperature is $24^{\circ} \mathrm{C}$, though temperatures usually keep on above $0{ }^{\circ} \mathrm{C}$. Temperatures can drop below freezing during some nights. The summer is very hot with a mean sunshine duration of about 12 hours/day and this season is usually dry with no rainfall. The temperature during the summer can rise more than $50{ }^{\circ} \mathrm{C}$ in shade. The mean temperature ranges during summer from $40{ }^{\circ} \mathrm{C}$ during the day to $24{ }^{\circ} \mathrm{C}$ at night. The annual average wind speed in Babylon Governorate is 7.2 $\mathrm{km} / \mathrm{h}$. The dominant wind direction in the governorate is northwest. For the years from 2005 to 2016, the mean annual rainfall was $102 \mathrm{~mm}$. The average annual proportion of relative humidity was $45.8[26,28,34$, 35].

\section{Methodology}

\subsection{Selection Sites for Landfill}

2.1.1 Estimated Future Quantities of Solid Waste Generated

The quantity of expected future solid waste in
Babylon and its districts for the year 2030 are calculated based on the expected population for each specific year as well as the rate of increment for waste generation rate in Babylon Governorate and its districts.

To calculate the population for each year from 2013 until 2030 Eq. (1) is used [36].

$$
\mathrm{PP}=\mathrm{PF}(1+\mathrm{r})^{\mathrm{n}}
$$

where, PP is the future population at the end of period; $\mathrm{PF}$ is the present population for year 2013; $\mathrm{r}$ is the annual growth rate of population $(2.99 \%)$ and $n$ is the number of years.

The present generation rate of solid waste for each district is calculated through divided the quantity of solid waste for the year 2013 by the population of each district for the year 2013 as follows Eq. (2):

$$
\operatorname{SWGR}_{(2013)}=\left(\mathrm{SWQ}_{(2013)}\right) /\left(\mathrm{PP}_{(2013)}\right)
$$

where, SWGR is the present generation rate of solid waste for the year 2013 (kg/capita/day); SWQ is the quantity of solid waste for the year $2013(\mathrm{~kg})$ and PP is the Population of district for the year 2013.

Generation rate of solid waste for each year is used to fulfill many factors such as improving living standards in the study area and increasing levels of commercial and industrial activities in urban areas.

This attempt is depending on the fact that waste generation rates in 2005 and 2013 to calculate the annual IWGR (increment of waste generation rate) as follows Eq. (3):

$$
\mathrm{IWGR}=\frac{\left(\mathrm{SWGR}_{2013}-\mathrm{SWGR}_{2005}\right)}{(\mathrm{n})}
$$

where, IWGR is the annual increment of waste generation rate $1 \%$; $\mathrm{SWGR}_{2013}$ is the generation rate of solid waste was 0.67 (kg/capita/day) of year 2013 [37, 38 ]; $\mathrm{SWGR}_{2005}$ is the generation rate of solid waste was $0.58(\mathrm{~kg} /$ capita/day) of year 2005 [28] and $\mathrm{n}$ is the period (years).

Equation (4) is used to calculate the generation rate of solid waste for year 2030 or specific year (GRSW).

$$
\operatorname{SWGR}_{(\mathrm{t})}=\operatorname{SWGR}_{(2013)}\left(1+\mathrm{IWGR}^{\mathrm{n}}\right.
$$

where, $\mathrm{SWGR}_{(\mathrm{t})}$ is the solid waste generation rate for 
each year (kg/capita/day); $\mathrm{SWGR}_{(2013)}$ is the present generation rate of solid waste for year 2013 from Eq. (2) and IWGR is the rate of annual increment in waste generation per year from Eq. (3) (similar to equation that used by Ref. [39]); $n$ is the number of years.

The main equation to calculate the waste quantity (SWQ) produced for each year until the year 2030 is as follows:

$$
\begin{gathered}
\text { SWQ (for specific year) }= \\
\left(\left(\mathrm{PP}_{(2013)}(1+0.0299)\right)^{\mathrm{n}}\right) \times \\
\left.\left(\mathrm{SWGR}_{(2013)}(1+0.01)^{\mathrm{n}}\right) \times(365 / 1000)\right)
\end{gathered}
$$

The cumulative quantity of solid waste generated by 2030 is calculated using Eq. (6).

$$
\mathrm{SWCQ}_{(\mathrm{c})}=\mathrm{SWQ}_{(\mathrm{ct})}+\mathrm{SWQ}_{(\mathrm{ct}-1)}
$$

where, $\mathrm{SWCQ}_{(\mathrm{c})}$ is the cumulative quantity of solid waste for the specific year (tonne); $\mathrm{SWQ}_{(\mathrm{ct})}$ is the quantity of solid waste for the specific year (tonne) and $\mathrm{SWQ}_{(\mathrm{ct}-1)}$ is the cumulative quantity of solid waste for the last year before specific year (tonne).

The quantity of solid waste in 2030, and the cumulative quantity of solid waste for the years (2020-2030) can be seen in Table 3.

The volume of waste for the year 2030 and the volume of cumulative waste from 2020 to 2030 in these districts are shown in Table 4. These values are calculated based on the following information:

- The information mentioned and summarized in Table 3 .

- These values of waste volume in 2030 are resulted by dividing the quantity solid waste in 2030 and the cumulative quantity of solid waste for the years (2020-2030) by the density of waste $\left(700 \mathrm{~kg} \mathrm{~m}^{-3}\right)$ [40-42].

\subsubsection{Siting Criteria}

The most important of 15 criteria were selected to obtain the best sites for landfill in the arid region (Babylon governorate, Iraq). The criteria and their categories that were adopted for the selected sites for landfill can be seen in Table 5. Geologically, clastic (fertile) materials known as alluvial deposits extend from the surface to a depth of more than $50 \mathrm{~m}$, where no rocks are exposed in this area [43].

In this study, based on reviews of literature in this field, opinions of experts and various existing required data about the study area, each criterion was classified into categories (sub-criteria), and each category was

Table 3 Expected solid waste quantity in 2030, and the solid waste cumulative quantity for the years (2020-2030).

\begin{tabular}{lllllll}
\hline District & $\mathrm{PP}_{(2013)}{ }^{\mathrm{a}}$ & $\mathrm{FP}_{(2030)} \mathrm{b}^{\mathrm{b}}$ & $\begin{array}{l}\mathrm{SWQ}^{\mathrm{c}}(2013) \\
(\text { Tonne })\end{array}$ & $\begin{array}{l}\mathrm{SWGR}^{\mathrm{d}}(2013) \\
(\mathrm{kg} / \text { capita/day })\end{array}$ & $\begin{array}{l}\mathrm{SWQ} \mathrm{(2030)} \\
(\text { Tonne })\end{array}$ & $\begin{array}{l}\mathrm{SWCQ}^{\mathrm{e}}(\mathrm{c})(2020-2030) \\
(\text { Tonne })\end{array}$ \\
\hline Al-Hillah & 807,777 & $1,332,930$ & 238,244 & 0.82 & 472,474 & $4,300,864$ \\
Al-Qasim & 184,605 & 304,621 & 38,913 & 0.57 & 76,374 & 695,219 \\
Al-Mahawil & 336,148 & 554,685 & 49,377 & 0.4 & 96,389 & 877,419 \\
Al-Hashimiyah & 270,020 & 445,566 & 51491 & 0.52 & 100,155 & 911,695 \\
Al-Musayiab & 374,684 & 618,274 & 105,196 & 0.77 & 205,792 & $1,873,295$ \\
Babylon Governorate & $1,973,234$ & $3,556,966$ & 483,221 & 0.67 & $1,030,174$ & $8,752,506$ \\
\hline
\end{tabular}

a PP: present population; ${ }^{\mathrm{b}} \mathrm{FP}$ : future population; ${ }^{\mathrm{c}}$ SWQ: solid waste quantity; ${ }^{\mathrm{d}}$ SWGR: generation rate of solid waste; ${ }^{\mathrm{e}}$ SWCQ: cumulative quantity of solid waste.

Table 4 Expected solid waste volume in 2030 and cumulative solid waste volume from 2020 to 2030 in Babylon Governorate and its districts.

\begin{tabular}{lll}
\hline District & Volume of waste in $2030\left(\mathrm{~m}^{3}\right)$ & Cumulative waste volume from 2020 to $2030\left(\mathrm{~m}^{3}\right)$ \\
\hline Al-Hillah & 674,963 & $6,144,091$ \\
Al-Qasim & 109,106 & 993,170 \\
Al-Mahawil & 137,699 & $1,253,456$ \\
Al-Hashimiyah & 143,079 & $1,302,421$ \\
Al-Musayiab & 293,989 & $2,676,136$ \\
Babylon Governorate & $1,471,677$ & $12,503,580$ \\
\hline
\end{tabular}


Table 5 The criteria and their categories that was selected for landfills siting in Babylon Governorate [44].

\begin{tabular}{|c|c|c|c|c|c|}
\hline Layer & Criteria & Categories & Score & Reference & Figure \\
\hline \multirow[t]{2}{*}{1} & G.W. depth (m) & $0.423-15.972$ & - & {$[11]$} & (Fig. 2a) \\
\hline & & $<5 \mathrm{~km}$ & 0 & & \\
\hline \multirow{3}{*}{2} & WL & $5-10$ & 10 & & \\
\hline & Urban centers $(\mathrm{km})$ & $10-15$ & 7 & [45] & (Fig. 2b) \\
\hline & & $>15 \mathrm{~km}$ & 4 & & \\
\hline \multirow{2}{*}{3} & Pivor $(1 \mathrm{~m})$ & $<1$ & 0 & 5157 & \\
\hline & River (km) & $>1$ & 10 & [45] & (F1g. 2c) \\
\hline \multirow{7}{*}{4} & Villoges (1rm) & $<1$ & 0 & {$[15]$} & (Fia $2 \mathrm{~d}$ ) \\
\hline & V1llages (Km) & $>1$ & 10 & [45] & (F1g. Zd) \\
\hline & & Periodically flooded soils (A7) & 10 & & \\
\hline & & Haur soils (B8) & 9 & & \\
\hline & & Basin depression soils (C6) & 9 & & \\
\hline & & River basin soils, poorly drained phase (D5') & 8 & & \\
\hline & & River basin soils, silted phase (E5) & 7 & & \\
\hline \multirow[t]{8}{*}{5} & Soils types & Silted haur and marsh soils (F9) & 6 & [46] & (Fig. 2e) \\
\hline & & River levee soils (G4) & 5 & & \\
\hline & & Active dune land (H11) & 4 & & \\
\hline & & Sand dune land (I18) & 3 & & \\
\hline & & Mixed gypsiferous desert land (J17) & 2 & & \\
\hline & & Gypsiferous gravel soils (K1) & 1 & & \\
\hline & & $0-0.5$ & 0 & & \\
\hline & & $0.5-1$ & 7 & & \\
\hline \multirow[t]{3}{*}{6} & Roads (km) & $1-2$ & 10 & [45] & (Fig. 2f) \\
\hline & & $2-3$ & 5 & & \\
\hline & & $>3$ & 3 & & \\
\hline 7 & Elevation (a.m.s.1.) & $11-72$ & & [45] & (Fig. 2g) \\
\hline \multirow{7}{*}{8} & & $0-5^{\circ}$ & 10 & & \\
\hline & Slope (degree) & $>5^{\circ}$ & 5 & [45] & (Fig. 2h) \\
\hline & & Industrial areas & 0 & & \\
\hline & & Urban Centers & 0 & & \\
\hline & & Villages & 0 & & \\
\hline & & Rivers & 0 & & \\
\hline & & Archaeological sites & 0 & & \\
\hline \multirow[t]{7}{*}{9} & Land use & Agricultural lands & 0 & & (Fig. 2i) \\
\hline & & University & 0 & & \\
\hline & & Treatment plant & 0 & & \\
\hline & & Agricultural airport & 0 & & \\
\hline & & Orchards & 5 & & \\
\hline & & Unused lands & 10 & & \\
\hline & & Agricultural lands & 0 & & \\
\hline \multirow[t]{3}{*}{10} & Agricultural land use & Orchards & 5 & [47] & (Fig. 2j) \\
\hline & & Unused lands & 10 & & \\
\hline & & $0-1$ & 0 & & \\
\hline \multirow[t]{2}{*}{11} & Archaeological sites $(\mathrm{km})$ & $1-3$ & 5 & {$[48]$} & (Fig. 2k) \\
\hline & & $>3$ & 10 & & \\
\hline \multirow{2}{*}{12} & Dower lines $(\mathrm{m})$ & $\leq 30$ & 0 & {$[45]$} & $(\mathrm{Fig} 21)$ \\
\hline & Power lines (m) & $>30$ & 10 & [45] & \\
\hline \multirow{2}{*}{13} & & $\leq 75$ & 0 & & \\
\hline & Oil pipelines (m) & $>75$ & 10 & [49] & (Fig. 2m) \\
\hline \multirow{2}{*}{14} & Gas nipelines $(\mathrm{m})$ & $\leq 250$ & 0 & {$[407$} & (Fig $2 n)$ \\
\hline & Gas pipelines (m) & $>250$ & 10 & [49] & (Fig. 2n) \\
\hline \multirow{2}{*}{15} & Railways $(\mathrm{km})$ & $0-0.5$ & 0 & {$[45]$} & $(\mathrm{Fig} 20)$ \\
\hline & & $>0.5$ & 10 & & \\
\hline
\end{tabular}




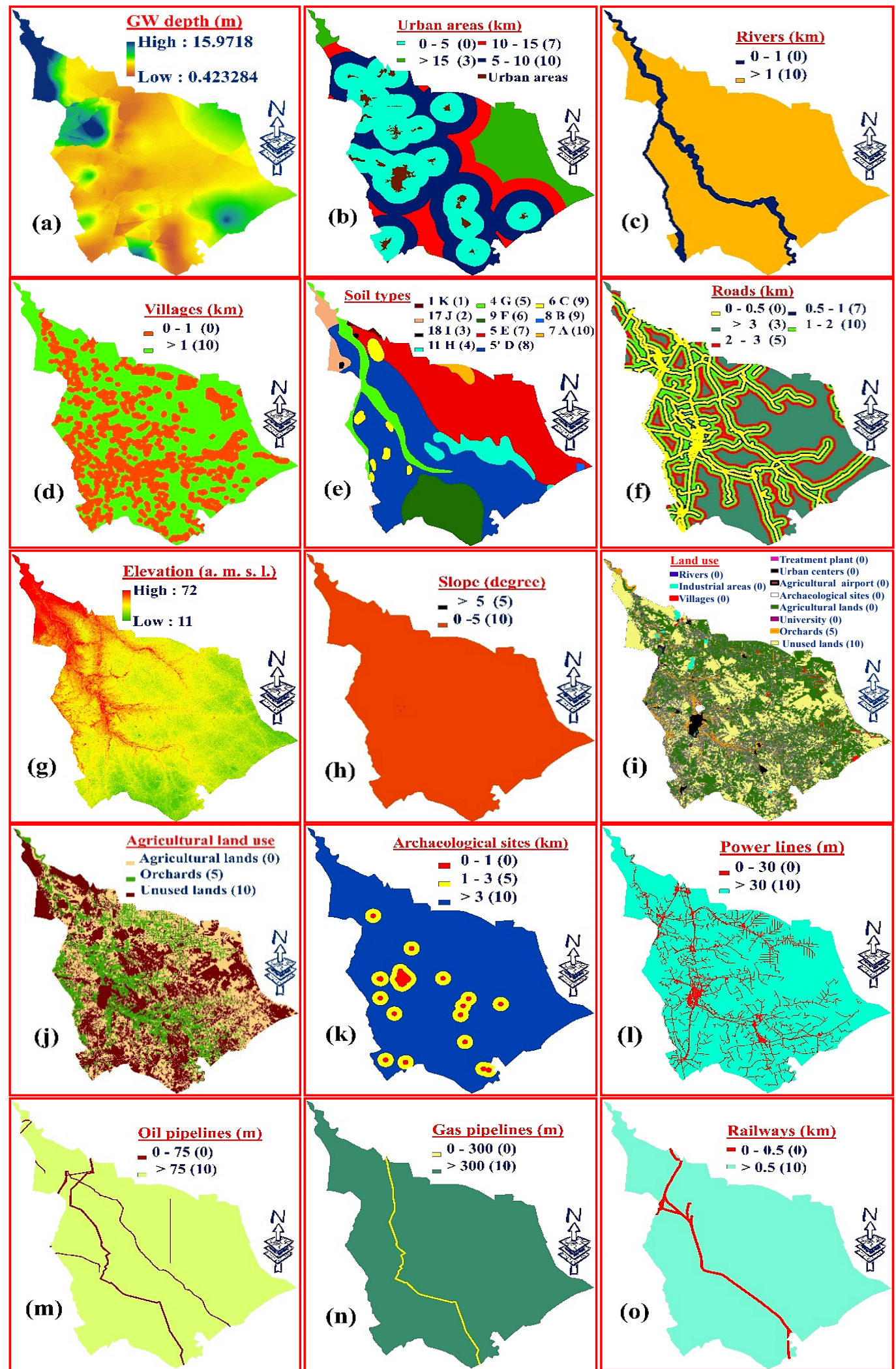

Fig. 2 Raster maps for Babylon Governorate are: (a): Ground water depth; (b): Urban center; (c): Rivers; (d): Villages; (e): Soil types; (f): Roads; (g): Elevation; (h): Slope; (i): Land use; (j): Agricultural land use; (k): Archaeological site; (l): Power lines; (m): Oil pipelines; (n): Gas pipelines; (o): Railways. 
given a suitability grading value. To prepare each criterion and sub-criteria, several steps should be performed in GIS software [44].

2.1.3 Selecting the Candidate Sites for Landfill

In Babylon Governorate, GIS software (10.5) and MCDM (multi-criteria decision making) methods (AHP (analytical hierarchy process), SRS (straight rank sum) and RSW (ratio scale weighting) were used to select the best candidate sites for landfill. The MCDM methods were applied to give the relative weights for criteria. The maps layers of 15 criteria were prepared in the GIS software. Finally, ten candidate sites were obtained on the final map(s) within the most suitable area category two for each district in Babylon Governorate [44, 50-54] (Table 6). On the satellite images of the Babylon Governorate, the selected candidate sites were checked (Fig. 3). The soil investigations for the new selected sites for landfill were conducted by the Iraqi Ministry of Housing \& Construction-National Center for Construction Laboratories and Research Babylon, Iraq in 2016 [55] to check the soil characteristics at each site and the depth of water table. According to Chabuk et al. [56], the results showed the data that entered in the maps of criteria were close with field tests.

\subsection{Landfills Site Layout}

The suggested landfill site should be divided into several zones, where each zone is sufficient to receive the waste quantity for a period of one year. In current study, the planned lifespan for the selected sites for landfill is 10 years. For each selected site, area is divided into 10 zones, where each zone is dedicated for the period of one year. The area of each zone is divided into number of cells to receive the waste quantity (for one month) based on the supposed lifespan for one zone (Fig. 4) [16]. Eq. (5) was used to calculate the SWQ for each year until the year 2030 [57].

For calculating the area of each zone $(\mathrm{km})$, the waste quantity $(\mathrm{kg}$ ) for a particular year is divided by the sum of multiplying the solid waste density $\left(700 \mathrm{~kg} / \mathrm{m}^{3}\right)$ by the waste height $(2 \mathrm{~m})$.

Table 6 The required area, and the areas and location of candidate sites for landfills in the districts of Babylon Governorate and the available area for design [44].

\begin{tabular}{|c|c|c|c|c|c|}
\hline \multirow{2}{*}{ District } & \multirow{2}{*}{ Requited area $\left(\mathrm{km}^{2}\right)$} & \multicolumn{2}{|c|}{ Area of candidate sites } & \multirow{2}{*}{ Location } & \multirow{2}{*}{$\begin{array}{l}\text { Available area for } \\
\text { design }\left(\mathrm{km}^{2}\right)\end{array}$} \\
\hline & & Site & Area $\left(\mathrm{km}^{2}\right)$ & & \\
\hline \multirow{2}{*}{ Al-Hillah } & \multirow{2}{*}{3.4} & $\mathrm{Hi}-1$ & 6.768 & $\begin{array}{l}\text { Latitude } 32^{\circ} 15^{\prime} 46^{\prime \prime} \mathrm{N} \\
\text { Longitude } 44^{\circ} 28^{\prime} 55^{\prime \prime} \mathrm{E}\end{array}$ & $\begin{array}{l}2.5 \times 1.5 \\
(3.75)\end{array}$ \\
\hline & & $\mathrm{Hi}-2$ & 8.204 & $\begin{array}{l}\text { Latitude } 32^{\circ} 13^{\prime} 43^{\prime \prime} \mathrm{N} \\
\text { Longitude } 44^{\circ} 29^{\prime} 15^{\prime \prime} \mathrm{E}\end{array}$ & $\begin{array}{l}2.5 \times 1.5 \\
(3.75)\end{array}$ \\
\hline \multirow{2}{*}{ Al-Qasim } & \multirow{2}{*}{0.55} & Q-1 & 2.766 & $\begin{array}{l}\text { Latitude } 32^{\circ} 11^{\prime} 43^{\prime \prime} \mathrm{N} \\
\text { Longitude } 44^{\circ} 32^{\prime} 26^{\prime \prime} \mathrm{E}\end{array}$ & $\begin{array}{l}0.8 \times 0.8 \\
(0.64)\end{array}$ \\
\hline & & Q-2 & 2.055 & $\begin{array}{l}\text { Latitude } 32^{\circ} 14^{\prime} 38^{\prime \prime} \mathrm{N} \\
\text { Longitude } 44^{\circ} 37^{\prime} 10^{\prime \prime} \mathrm{E}\end{array}$ & $\begin{array}{l}0.8 \times 0.8 \\
(0.64)\end{array}$ \\
\hline \multirow{2}{*}{ Al-Hashimiyah } & \multirow{2}{*}{0.72} & Hs-1 & 1.288 & $\begin{array}{l}\text { Latitude } 32^{\circ} 15^{\prime} 54^{\prime \prime} \mathrm{N} \\
\text { Longitude } 44^{\circ} 53^{\prime} 38^{\prime \prime} \mathrm{E}\end{array}$ & $\begin{array}{l}1 \times 0.8 \\
(0.8)\end{array}$ \\
\hline & & Hs-2 & 1.374 & $\begin{array}{l}\text { Latitude } 32^{\circ} 24^{\prime} 43^{\prime \prime} \mathrm{N} \\
\text { Longitude } 44^{\circ} 55^{\prime} 43^{\prime \prime} \mathrm{E}\end{array}$ & $\begin{array}{l}1 \times 0.8 \\
(0.8)\end{array}$ \\
\hline \multirow{2}{*}{ Al-Mahawil } & \multirow{2}{*}{0.7} & Мa-1 & 2.950 & $\begin{array}{l}\text { Latitude } 32^{\circ} 29^{\prime} 59^{\prime \prime} \mathrm{N} \\
\text { Longitude } 44^{\circ} 41^{\prime} 2^{\prime \prime} \mathrm{E}\end{array}$ & $\begin{array}{l}1 \times 0.8 \\
(0.8)\end{array}$ \\
\hline & & Ma-2 & 2.218 & $\begin{array}{l}\text { Latitude } 32^{\circ} 38^{\prime} 12^{\prime \prime} \mathrm{N} \\
\text { Longitude } 44^{\circ} 34^{\prime} 9^{\prime \prime} \mathrm{E}\end{array}$ & $\begin{array}{l}1 \times 0.8 \\
(0.8)\end{array}$ \\
\hline \multirow{2}{*}{ Al-Musayiab } & \multirow{2}{*}{1.4} & Mu-1 & 7.965 & $\begin{array}{l}\text { Latitude } 32^{\circ} 48^{\prime} 39^{\prime \prime} \mathrm{N} \\
\text { Longitude } 44^{\circ} 8^{\prime} 59^{\prime \prime} \mathrm{E}\end{array}$ & $\begin{array}{l}2 \times 1 \\
(2)\end{array}$ \\
\hline & & $\mathrm{Mu}-2$ & 5.952 & $\begin{array}{l}\text { Latitude } 33^{\circ} 0^{\prime} 14^{\prime \prime} \mathrm{N} \\
\text { Longitude } 44^{\circ} 66^{\prime} 46^{\prime \prime} \mathrm{E}\end{array}$ & $\begin{array}{l}2 \times 1 \\
(2)\end{array}$ \\
\hline
\end{tabular}


Application of the HELP Model for Landfill Design in Arid Areas: Case Study

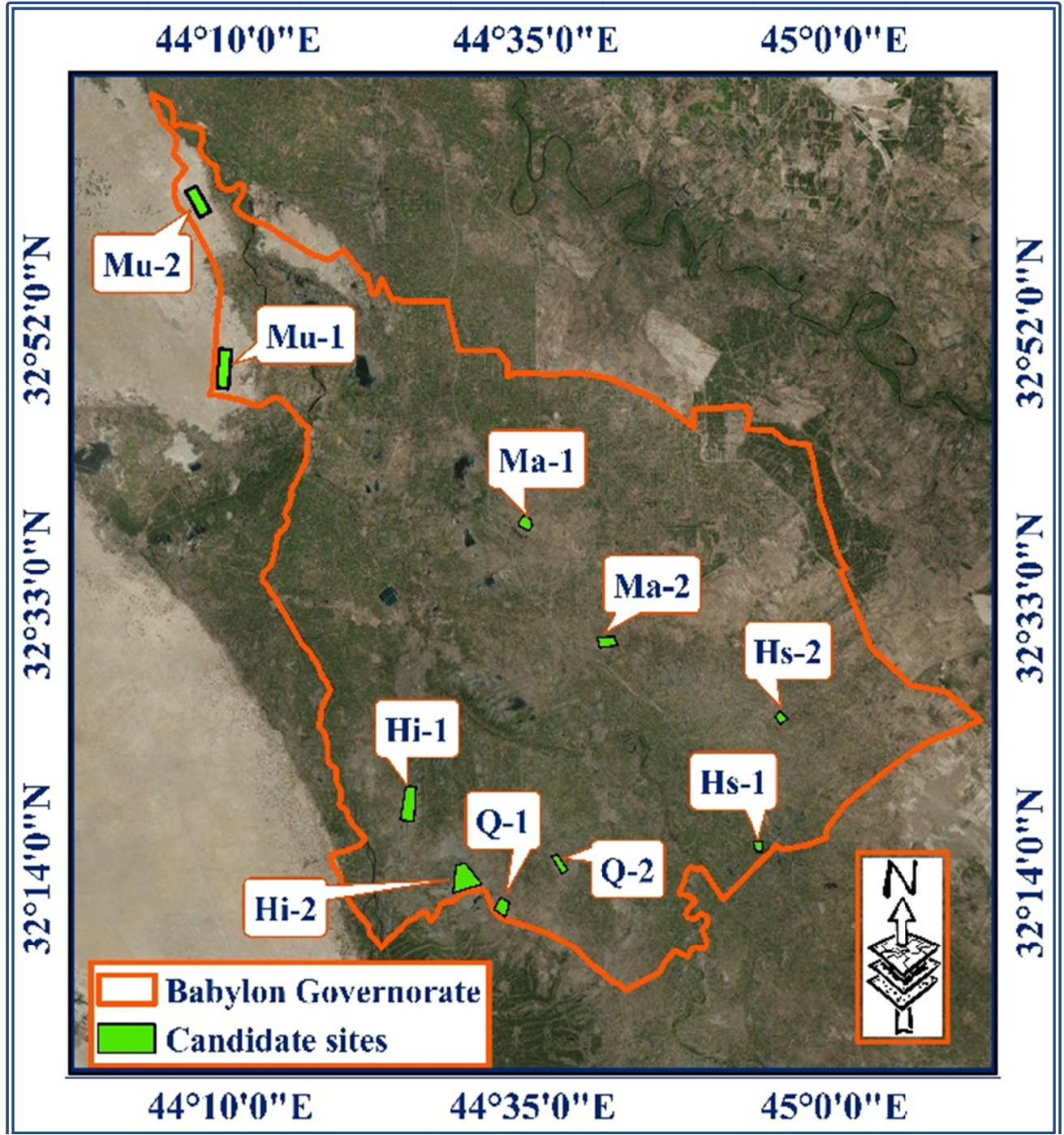

Fig. 3 Candidate selected sites for landfill in the Babylon Governorate.

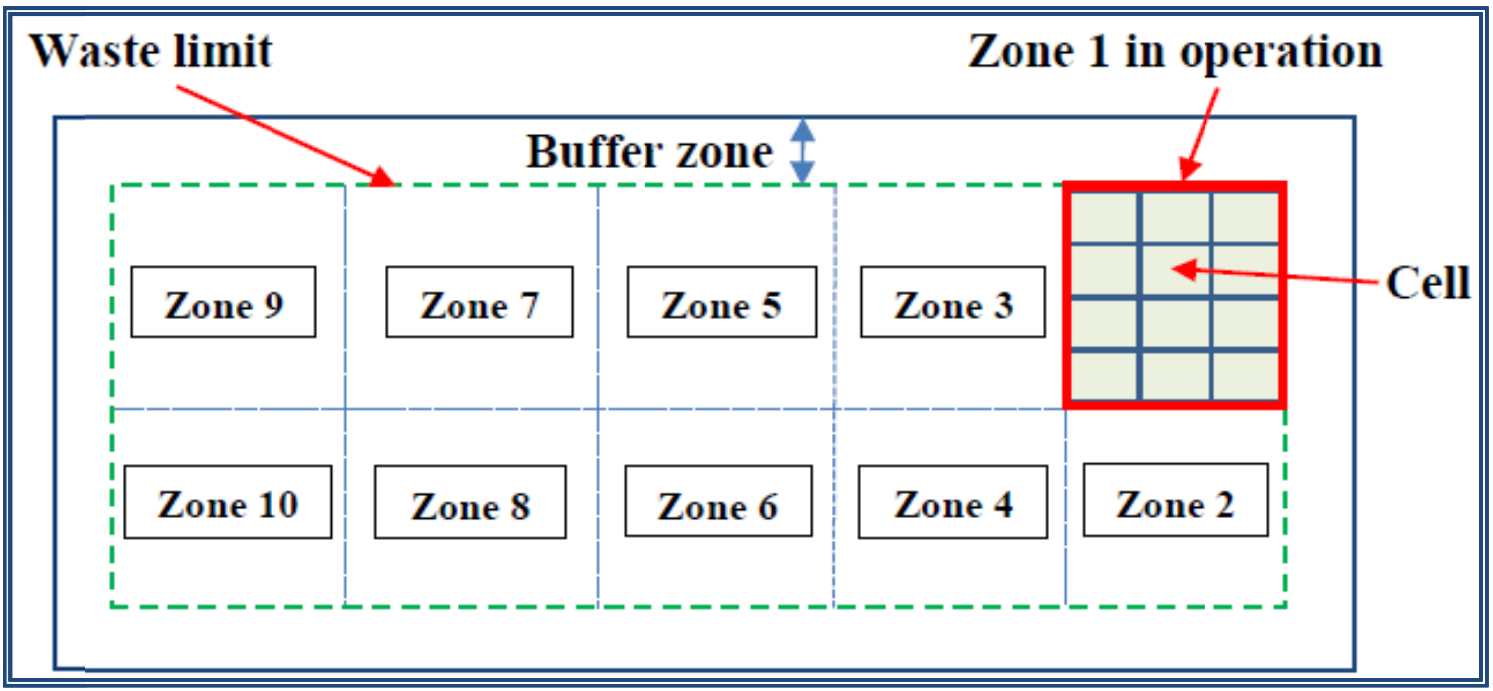

Fig. 4 The suggested plane sketch diagram for a landfill site. 


\subsection{Suggested Landfill Design}

The main goal of landfill design in the arid area (Babylon Governorate, Iraq) is to reduce the effects of solid waste on human health and surrounding environment. The suggested design of landfill includes the soil layers for base liner system and final cover system. These layers are as follows:

\subsubsection{Base Liner System}

The main aim of construction the base liner system is to prevent groundwater contamination by the leachate [20]. The suggested soil layers for the base liner system in the arid area (Babylon governorate, Iraq) from the bottom to the top are as follows:

\section{(a) Sub-base layer}

The compacted layer of sub-base is necessary to provide a stable and smooth ground surface for the bottom barrier layer constructed on it without affecting the bottom barrier layer by differential settlement. This layer should be compacted and placed directly over the compacted natural soil. The thickness of the sub-base layer is $20 \mathrm{~cm} \mathrm{[58]} \mathrm{or} 30 \mathrm{~cm}$ [59-61]. The sub-base layer is compacted with maximum modified proctor's density of $90-95 \%$ using two lifts or $80-90 \%$ if using sandy materials [59]. In the current design, the thickness of the sub-base layer is between $20-30 \mathrm{~cm}$.

(b) Bottom barrier layer (liner system)

The main objective of using bottom barrier layer in a landfill is to inhibit groundwater pollution by leachate. This layer is used to filter the leachate within it and to prevent the leachate percolation through it, and flow laterally $[24,59,62]$.

The barrier layer of a landfill consists of the following common types [13, 63]. The barrier layer contains composite soils' materials with low permeability such as sandy clay and silty clay. The geomembrane liner is placed over composite barrier layer in this type. For bottom barrier layer, the final surface should be smooth to provide quick lateral drainage for leachate over the liner [20].

In current suggested design, the composite bottom barrier layer (high compacted sandy clay) is preferred to use with hydraulic conductivity of $1.0 \mathrm{E}-7 \mathrm{~cm} / \mathrm{s}$. The thickness of this layer is $60 \mathrm{~cm}$ with compacted lifts (each lift is $15 \mathrm{~cm}$ ). On the surface of each lift, should be made scratches to increase cohesion and bonding between each two lifts.

(c) Geomembrane layer

The geomembrane liner is used (together with the bottom barrier layer) to reduce the flow of pollutants' quantity percolation through it that affecting the groundwater [63]. The geomembrane liner life should be 100 years depending on expected operating years, weather parameters (especially temperature) and a thickness of $\leq 1.5 \mathrm{~mm}[25,59]$.

The suggested geomembrane's liner should take into consideration many factors, including susceptibility to deterioration or chemical attack, deformation, its thermal stability, elasticity and tensile strength, shear resistance, puncture and tear resistance, local environmental conditions, and slope stability [20].

A geomembrane on a slope should be fixed by anchor trenches to prevent it from slipping down inside the side slopes during construction [20,59]. The width of the anchor trench should be $50 \mathrm{~cm} \mathrm{[60]} \mathrm{or} 60-90 \mathrm{~cm}$ [59], and its depth is $60 \mathrm{~cm}$ [59].

In this design, the type of geomembrane liner placed within the base liner system includes a flexible membrane liner of HDPE (high-density polyethylene) with a thickness of $1.5 \mathrm{~mm}$, and its hydraulic conductivity is $2.0 \mathrm{E}-13 \mathrm{~cm} / \mathrm{s}$.

(d) Leachate collection system

The leachate collection system is used to remove the percolated leachate from the waste zone. The leachate is resulted from rainfall that infiltrated through the layers of the final cover system then into the waste zone, as well as leachate from waste itself. The percolated leachate that is rising above bottom barrier layer is transported to the leachate collection pond or treatment facility by collection pipes of leachate $[8,24$, 25]. This system consists of the drainage blanket layer (gravel) and leachate collection pipes. In this suggested 
design, the general requirements design for leachate collection system is as follows:

The drainage blanket layer contains of gravel material with thickness of $30 \mathrm{~cm}[23,25,58,62]$. To avoid chemical attack, the drainage layer should not be containing limestone or other calcareous material [20]. The hydraulic conductivity of the drainage blanket layer is $1.0 \mathrm{E}-3 \mathrm{~m} / \mathrm{s}[8,24,25,58]$. To avoid clogging and capillary action that can hold water in the drainage layer and to provide space into the drainage layer to drain leachate freely, coarse material is used [20].

The leachate collection pipes comprise the slotted bottom pipes of leachate collection (main drainpipes and lateral pipes) and the main header pipe. The diameter of the main drainpipes is between $15-20 \mathrm{~cm}$, where the diameter of main drainpipes is $\geq 15 \mathrm{~cm}[58$, 62] or $20 \mathrm{~cm} \mathrm{[24]} \mathrm{or} 30 \mathrm{~cm} \mathrm{[64].} \mathrm{The} \mathrm{lateral} \mathrm{spacing} \mathrm{for}$ the main drainpipes is $\geq 25 \mathrm{~m}$ [58]. The longitudinal slope of main drainpipes toward the main header pipe or sump should be $\geq 1 \%[24]$ or $\geq 2 \%$ [58].

The vertical and inclined pipes are installed over the leachate collection pipes [65]. The inclined pipes are distributed on inside slope of the perimeter berm. The vertical and inclined pipes are used as vents for releasing the gases into atmosphere [65].

The lateral pipes connecting with the main drainpipes, and the interval space between each lateral pipe is $2 \mathrm{~m} \mathrm{[59].} \mathrm{The} \mathrm{slope} \mathrm{of} \mathrm{lateral} \mathrm{pipes} \mathrm{in} \mathrm{the}$ transverse direction toward the main drain pipes should be $\geq 2 \%[24]$ or $\geq 3 \%$ [58].

The main header pipe is to be placed around the site cells and linked with the main drainpipes. The main header pipe acts to remove the leachate to the sump by gravitational force [24, 65]. The inspection shafts (cleaning points) should be placed along the main header pipe (outside the zone of waste), at the main drainpipes and lateral pipes ends and at the connecting points of the main drainpipes with the main header pipe [63].

The sump usually situates at the low points in cells of landfill, where that it is located either outside or inside the landfill site [24, 65]. To remove and lift leachate from the sump to the required head, an operating pump should be used [24]. Then, the collected leachate should be removed by pumping to the leachate collection pond or to the leachate treatment facility directly or the leachate can be stored in the leachate storage tank and sent it to waste-water treatment plants (when the amount of leachate generated is low) [8]. After treating the leachate in the treatment facilities, the treated leachate can be sent back into the landfill to promote the waste decomposition [66]. The sketch of layout for the leachate collection system in landfills can be seen in Fig. 5.

(e) Protection layer

The protection layer should be placed over the drainage layer to ensure the long-term operation of the drainage layer since it prevents waste particles from moving into the drainage layer, does not destroy the drainage pipes and prevent clogging the drainage layer $[8,24]$. To prevent the retention of leachate in the mass of waste, the hydraulic conductivity of the protective layer should be more than $1.0 \mathrm{E}-5 \mathrm{~cm} / \mathrm{s}$ [8]. The suggested thickness of the protection layer is among 30 $\mathrm{cm}, 50 \mathrm{~cm}$ [8] and $30 \mathrm{~cm} \mathrm{[59].}$

A non-wave geotextile filter layer can be used and placed over the drainage layer instead of the protection layer [20,58]. This layer performs same function of sand materials as a protection layer to the drainage layer.

In the current design, the protection layer consists of sand and its hydraulic conductivity is equal to $5.0 \mathrm{E}-3$ $\mathrm{cm} / \mathrm{s}$. The thickness of this layer is $30 \mathrm{~cm}$.

\subsubsection{Waste Zone}

In this study, the waste is suggested to place over the ground surface because the groundwater depth in Babylon Governorate, Iraq is shallow. In the selected sites for landfill, the suggested height of the waste is 2 $\mathrm{m}[42,67]$ after compacting it in situ to the density of $700 \mathrm{~kg} / \mathrm{m}^{3}$ [40-42]. 


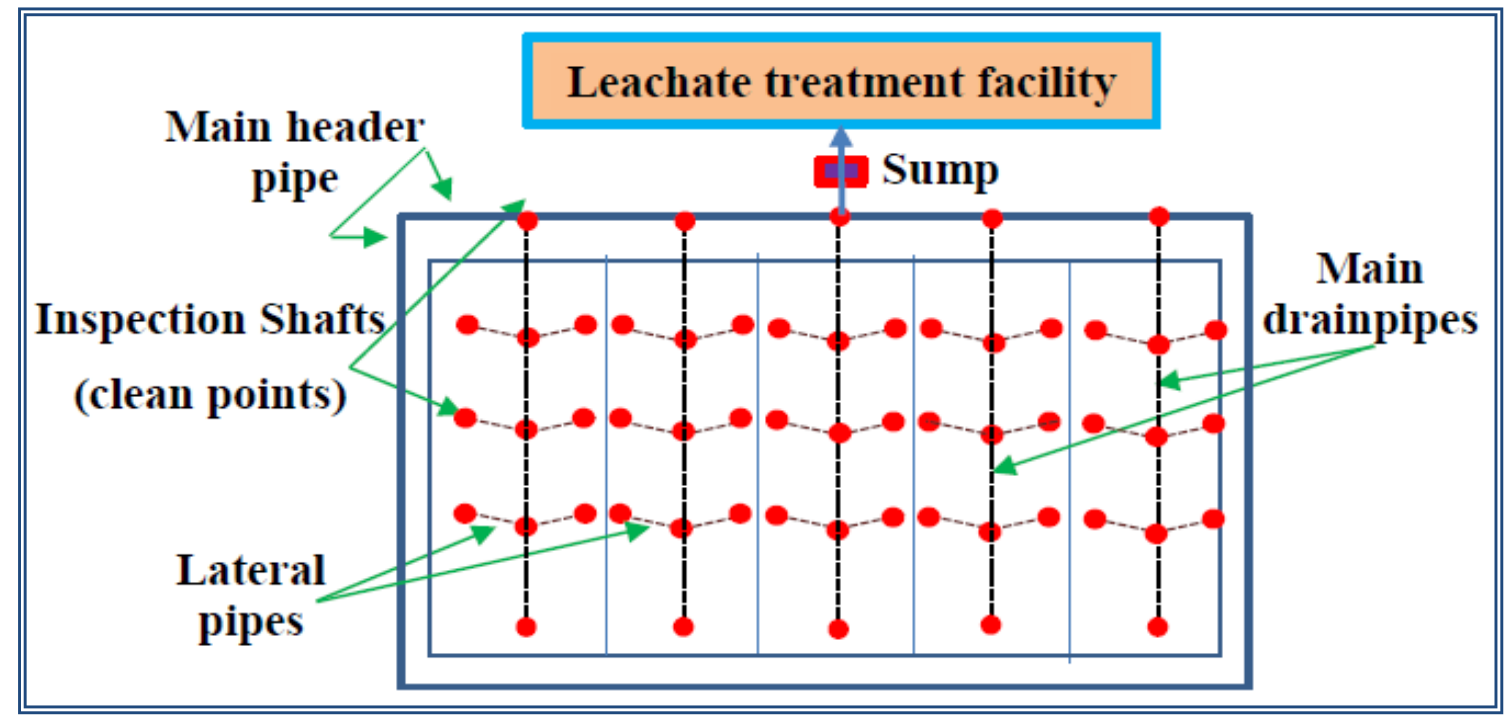

Fig. 5 The suggested sketch for the leachate collection system layout in the landfills.

In the site, the waste is spread and compacted in thin lifts of $0.5 \mathrm{~m}$ [25]. The compacting equipment passes (normally 3-5 times) over the waste to achieve the required compaction [25]. A soil of $15 \mathrm{~cm}$ thick should be used daily to cover the waste mass to minimize the environmental risk that resulted from landfill on human health. Fig. 6 shows the suggested soils layers for base liner system.

\subsubsection{Final Cover System}

The final cover system of landfill is used when a volume of waste in landfill reaches to maximum capacity. The main aims of placing the final cover system on a landfill are: (i) To prevent humans and environment from exposure to municipal solid waste; (ii) To reduce odors, noise, diseases, etc.; (iii) To decrease infiltration of precipitation into the waste body, consequently, prevent the leachate generation; (iv) Controlling surface erosion by promote drainage; (v) The surface becomes more stabilized for the completed part of the landfill; (vi) Ensuring maintenance of the cover to prevent accommodate settling and subsidence; (vii) Controlling the gas emission from landfill $[8,22,58]$.

The first scenario "Evapotranspiration soil cover (ET), (capillary barriers type)" was applied, using the available local soil materials in the suggested layers of the final cover system. This type of cover system is mostly applied recently for landfills in arid areas in the USA and other developed countries [10, 68]. The second scenario of the modified cover design of "RCRA Subtitle D", is also applied in arid areas, and which is considered the cheapest system according to Ref. [10]. The suggested designs for the layers (from bottom to top) and their specifications for the final cover system using the "evapotranspiration soil cover (ET), (capillary barriers type)", and the modified design of "RCRA Subtitle D" can be seen in Table 7 [15]. For the final cover, the positive features for certain layers from the modified cover design of "RCRA Subtitle D" (first scenario) and “evapotranspiration (ET), capillary barriers" (second scenario) according to Chabuk et al. (2018) [15] were taken for the "Recommended design" (third scenario) for the landfill in the arid area (Babylon governorate, Iraq).

In the "Recommended design" (third scenario) [15], for the layers of the final cover system, the support vegetation layer consists of the fine particles (moderate compacted loam). The fine particles in this layer enable it to store the infiltrated water from the surface until it evaporates from the topsoil layer depending on the high temperature during most of the months in the arid area [68]. The top barrier layer and the geomembrane liner are placed beneath the support vegetation layer. These 


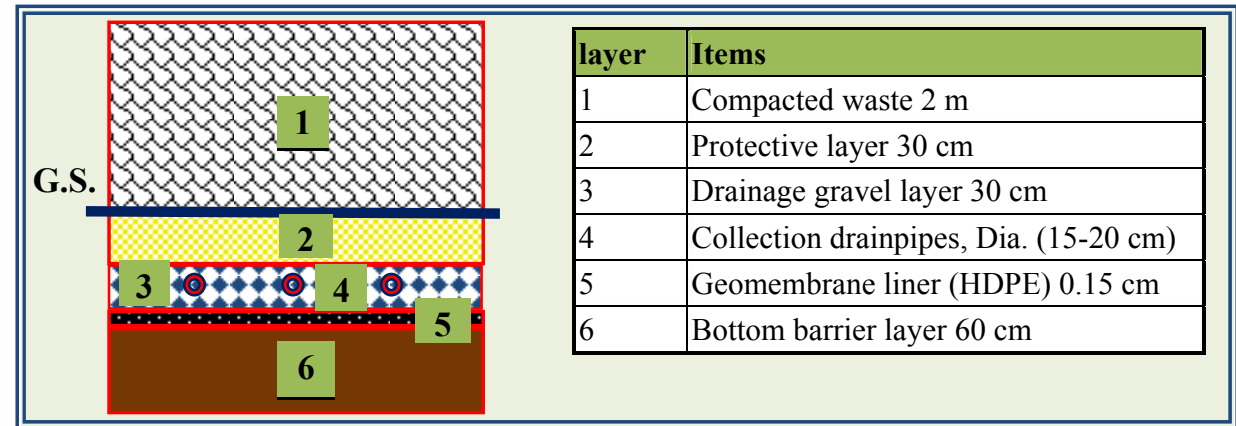

Fig. 6 The sketch of the suggested soils layers for base liner system.

Table 7 Suggested layer data for the landfill design, using the first and second scenario [15].

\begin{tabular}{llll}
\hline Layer & Material & Thickness & Hydraulic conductivity \\
\hline \multicolumn{2}{l}{ First scenario "evapotranspiration soil cover (ET), (capillary barriers type)” } & & \\
\hline 1 & Intermediate cover (moderately compacted silty clay loam) & $30 \mathrm{~cm}$ & $1.0 \mathrm{E}-6 \mathrm{~cm} / \mathrm{s}$ \\
2 & Coarse-particle soil (coarse sand). & $30 \mathrm{~cm}$ & $1.0 \mathrm{E}-2 \mathrm{~cm} / \mathrm{s}$ \\
3 & Fine-particle soil layer (moderately compacted loam). & $75 \mathrm{~cm}$ & $1.0 \mathrm{E}-5 \mathrm{~cm} / \mathrm{s}$ \\
4 & Topsoil layer (silty clayey loam) & $15 \mathrm{~cm}$ & $4.0 \mathrm{E}-5 \mathrm{~cm} / \mathrm{s}$ \\
\hline Second scenario "RCRA Subtitle D" (modified design) & & \\
\hline 1 & Intermediate cover (moderately compacted silty clay loam) & $30 \mathrm{~cm}$ & $1.0 \mathrm{E}-6 \mathrm{~cm} / \mathrm{s}$ \\
2 & foundation layer (coarse sand) & $30 \mathrm{~cm}$ & $1.0 \mathrm{E}-2 \mathrm{~cm} / \mathrm{s}$ \\
3 & Top barrier layer (highly compacted sandy clay) & $45 \mathrm{~cm}$ & $1.0 \mathrm{E}-7 \mathrm{~cm} / \mathrm{s}$ \\
4 & Topsoil layer (silty clay loam) & $15 \mathrm{~cm}$ & $4.0 \mathrm{E}-5 \mathrm{~cm} / \mathrm{s}$
\end{tabular}

layers work together to prevent water percolation through the waste body and reduce the leachate generation. The top barrier layer contains the high compacted sandy clay that is available locally in Babylon governorate and generally in Iraq.

To reduce the risk of sliding and erosion in the landfill, the side slope of final cover at landfill site should be $33.3 \%$ (3H:1V) [25, 65] or $>40 \%$ (2.5H: $1 \mathrm{~V})$ [24].

To prevent erosion and/or pooling and to enhance water runoff on the surface of a landfill, the slope of the top surface (plateau) for the final cover of a landfill should be $3.3 \%$ (30H:1V) [24] or 3.3-5\% (30-20H:1V) [23] or $10 \%(10 \mathrm{H}: 1 \mathrm{~V})$ [25].

For the third scenario "Recommended design" for the final cover system of landfills design in arid area like Babylon governorate, the layers (from bottom to top) and there are as follows:

(a) Cover of intermediate soil

In this study, the intermediate cover of $30 \mathrm{~cm}$ thick consists of moderately compacted silty clay loam, and its hydraulic conductivity is $1.0 \mathrm{E}-6 \mathrm{~cm} / \mathrm{s}$. In the current design, the intermediate soil layer of $30 \mathrm{~cm}$ is suggested for covering the waste mass when it reaches the peak height that is required in the design or during the rainfall season. Intermediate soil cover is placed over the waste body and should be monitored for a certain period before setting the top barrier layer and other layers of the final cover system over intermediate cover. This is to avoid settlement and change in the volume of layers of the final cover system when organic material within the waste mass is decomposed $[8,23,25,60]$.

(b) Foundation layer

The foundation layer acts as a cushion for layers of the final cover system [23]. This layer consists of coarse sand with thickness of $30 \mathrm{~cm}$, and its hydraulic conductivity is $\geq 1.0 \mathrm{E}-2 \mathrm{~cm} / \mathrm{s}$. The gas collection system is installed within the foundation layer [23].

(c) Top barrier layer (final cover system)

The composite top barrier consists of high compacted sandy clay, and it is placed over the 
foundation layer. The thickness of this layer is between $45-60 \mathrm{~cm}$. The hydraulic conductivity should be $\leq$ $1.0 \mathrm{E}-7 \mathrm{~cm} / \mathrm{s}$.

Before placing the other layers over it, this layer should be monitored to treat the displacement and the spaces that left on the layer surface when the waste materials degrade.

The composite top barrier layer should have a fixed thickness of 45 or $60 \mathrm{~cm}$ over a precise period [8]. In Babylon Governorate, the waste contains a high percentage of organic material more than $55 \%$ [37, 38]. The organic usually decomposes with time, and this may be caused settlement for the surface layer and being irregular (not horizontal). In this situation, similar soil materials of high compacted sandy clay are added for this layer when the displacement at the surface of top barrier layer stops during a specific period or during the landfill span life to keep the surface smooth as possible as. Therefore, the final thickness of top barrier layer should be 45 or $60 \mathrm{~cm}$.

(d) Geomembrane liner layer (final cover system)

The geomembrane layer (HDPE) to be placed on the top barrier layer with thickness of $0.5 \mathrm{~cm}$ [40], and its hydraulic conductivity is $2.0 \mathrm{E}-13 \mathrm{~cm} / \mathrm{s}$. The geomembrane is used to conserve water saturation limit in the top barrier layer and protect it from cracks that resulted from high temperature in the arid areas [58]. The geomembrane supports the top barrier layer through preventing water infiltration into the waste from the surface of landfill and minimizing the leachate generation as well as controlling the gas emission.

(e) The top layer (final cover system)

The top layers are used so that vegetation can grow and reduce potential of surface erosion. The top layers include two parts. These are the support vegetation layer and the topsoil layer.

The support vegetation layer acts as a rooting layer for the vegetation on the surface of top soil layer. The roots of the vegetation should not extend too deeply, and without woody plants because this would allow damage to the final cover and thus pollutants can be transferred to the surrounding environment. The fine particles in this layer enable it to store water that infiltrated from the surface until evaporation $[8,24,25$, 58].

In the suggested design, the support vegetation layer consists of moderate compacted loam, and its hydraulic conductivity is $1.0 \mathrm{E}-5 \mathrm{~cm} / \mathrm{s}$. The thickness of the support vegetation layer is between $45-60 \mathrm{~cm}$.

The topsoil layer contains silty clayey loam materials that available locally in Babylon governorate. The hydraulic conductivity of topsoil layer is $4.0 \mathrm{E}-5$ $\mathrm{cm} / \mathrm{s}$, and its thickness is $15 \mathrm{~cm}$.

The side slope of final cover of the landfill site should be $30.3 \%$ ( $3 \mathrm{H}: 1 \mathrm{~V})$ while the slope of the top surface for the final cover of the landfill is $3.3 \%$ $(30 \mathrm{H}: 1 \mathrm{~V})$. The layers of the final cover system can be seen in Fig. 7.

\subsection{Bearing Capacity and Deformation in the Layers of Landfill}

According to the Iraqi Ministry of Housing \& Construction [55], the bearing capacity for the soils of the selected sites is $50 \mathrm{KN} / \mathrm{m}^{2}$. Consequently, according to Laue et al. [69], this value should be taken into consideration when constructing the required infrastructure or other facilities above a site's surface during, or at the end of, a landfill's lifespan for a newly selected site in the future to avoid deformation in the bottom barrier layer.

In the current design, the cumulative load results from using a $2 \mathrm{~m}$ height of compacted waste, the layers of the final cover system, together with daily coverings of soil with many lifts (daily additive) of $15 \mathrm{~cm}$. According to Laue et al. [69], the cumulative loads of compressive stress that result from the layers on top of the ground surface can cause deformation in the bottom barrier layer. Thus, the overloads that come from the layers of the final cover system, and the waste will lead to increased deformation in the bottom barrier layer, and this will increase the subsidence for the cover layers that are set over it. This can then cause cracks in 


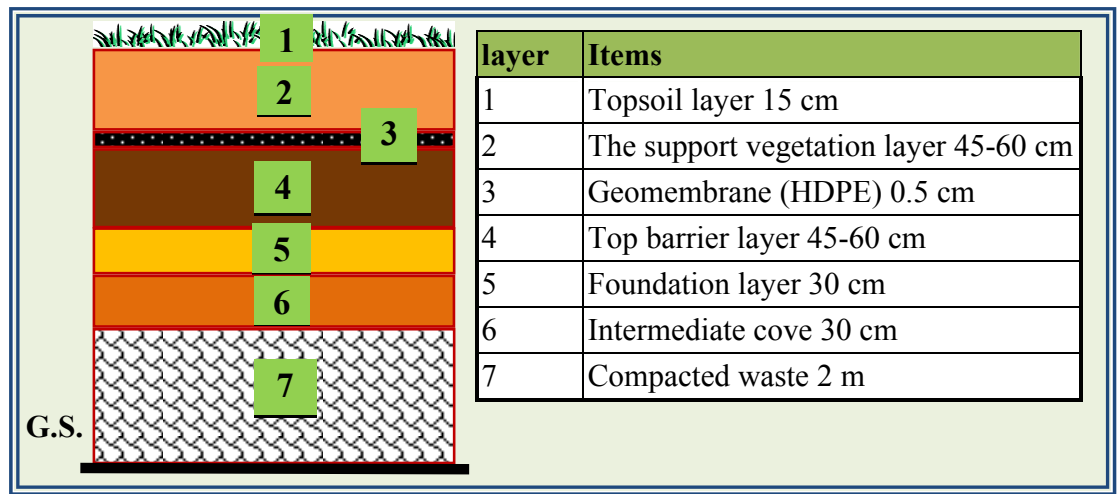

Fig. 7 Sketch of the suggested soil layers for the final cover system.

Table 8 Densities of different materials used in the landfill design [70].

\begin{tabular}{llll}
\hline \multirow{2}{*}{ No. } & Material & \multicolumn{2}{c}{ Density $(\rho)\left(\mathrm{kg} / \mathrm{m}^{3}\right)$} \\
\cline { 3 - 4 } & & Max. & Min. \\
2 & Compacted waste. & 700 & 700 \\
3 & Silty clayey loam (daily cover). & 2,170 & 1,553 \\
4 & Silty clayey loam (topsoil layer). & 2,085 & 1,475 \\
5 & Sand (protection layer). & 2,290 & 1,619 \\
6 & Course sand (foundation layer). & 2,371 & 1,378 \\
7 & Gravel (driange layer). & 2,499 & 2,002 \\
8 & Moderately compacted loam (supported vegetation layer). & 1,625 \\
9 & Moderately compacted silty clayey loam (intermediate layer). & 2,300 & 1,553 \\
\hline
\end{tabular}

the top barrier layer. For different materials, the densities which were used in the suggested design layers for landfill can be seen in Table 8 [70].

The primary settlement in the bottom barrier layer under the stress of compacted solid waste $\left(700 \mathrm{~kg} / \mathrm{m}^{3}\right)$ with a height of $2 \mathrm{~m}$ was calculated as follows [71]:

(1) Calculating the change or increase in effective vertical stress $\left(\Delta \sigma 0^{\prime}\right)$.

$\Delta \sigma \mathrm{o}_{2 \mathrm{~m}}^{\prime}=$ compacted waste stress + daily cover stress + intermediate cover stress + foundation layer stress + top barrier layer stress + supported vegetation layer stress + topsoil layer stress

$$
\begin{aligned}
& \Delta \sigma \mathrm{o}_{2 \mathrm{~m}}^{\prime}=0.7 \times 9.81 \times 2+2.17 \times 9.81 \times 0.15 \times 3 \\
& +2.17 \times 9.81 \times 0.3+2.29 \times 9.81 \times 0.3+2.355 \times 9.81 \times \\
& 0.45+2.3 \times 9.81 \times 0.45+2.085 \times 9.81 \times 0.15 \\
& \Delta \sigma o^{\prime}{ }_{2 \mathrm{~m}}=60 \mathrm{kpa}
\end{aligned}
$$

Using factor of safety 1.3

$$
\Delta \sigma o_{2 \mathrm{~m}}^{\prime}=78 \mathrm{kpa}
$$

(2) Calculating the effective vertical stress $\left(\sigma o^{\prime}\right)$ in the middle of layer after excavation before loading. $\sigma 0^{\prime}=$ course sand stress + gravel stress + bottom barrier layer stress

$$
\begin{aligned}
\sigma o^{\prime} & =2.371 \times 9.81 \times 0.3+2.499 \times 9.81 \times 0.3+\frac{1}{2} \\
\times 2.335 \times 9.81 \times 0.6 & \\
\sigma o^{\prime} & =21 \mathrm{kpa}
\end{aligned}
$$

(3) Calculating the primary settlement in the bottom barrier layer.

- Assumed initial void ratio $=0.41$ [72].

- Assumed primary compression index $=0.15$ [73].

- The thickness above the bottom barrier layer $=60$ $\mathrm{cm}$.

$$
\mathrm{S}_{\mathrm{c} 2 \mathrm{~m}}=\left(\frac{C_{c}}{1+e_{o}}\right) \times H \times \log \left(\frac{\check{\sigma_{0}+\Delta \sigma_{0}}}{\sigma_{0}^{\prime}}\right)
$$

$\mathrm{S}_{\mathrm{c}}$ : Primary settlement (mm); H: The layer thickness to be evaluated after excavation; $\mathrm{C}_{\mathrm{c}}$ : Primary compression index; $\mathrm{e}_{0}$ : Initial void ratio; $\sigma o^{\prime}$ : Effective vertical stress at the middle of layer after excavation before loading and $\Delta \sigma o^{\prime}$ : Change or increase in effective vertical stress because of the loading. 


$$
\mathrm{S}_{\mathrm{c} 2 \mathrm{~m}}=\left(\frac{0.15}{1+0.41}\right) \times 0.6 \times \log \left(\frac{21+78}{21}\right)=4.0 \mathrm{~cm}
$$

Therefore, the primary settlement in the bottom barrier layer under the stress of compacted solid waste and other layers over it including the layers of the final cover system was equal to $4 \mathrm{~cm}$.

\subsection{Perimeter Berm}

The perimeter berm forms the upslope boundaries around the landfill site as a natural barrier for the site to prevent storm-water from entering the site and to reduce soil erosion. In addition, the embankment of the perimeter berm is used for the passage of vehicles to the site $[21,60]$.

According to Ref. [59], the height of the berm should be 3-4 m, and a berm with a slope of $3 \mathrm{H}: 1 \mathrm{~V}$ is considered safe and stable against collapse. Ref. [60] found the minimum height of the berm should be $2 \mathrm{~m}$, but the typical height of berms ranges between 2.5 and $3.5 \mathrm{~m}$. The required crest width for the berm is $2 \mathrm{~m}$. The inside and outside slopes of the berm are $3 \mathrm{H}: 1 \mathrm{~V}$ and $2 \mathrm{H}: 1 \mathrm{~V}$, respectively. Ref. [21] suggested the typical height of the berm is $2 \mathrm{~m}$, and the wide crest of the berm is $1 \mathrm{~m}$ with a slope of $3 \mathrm{H}: 1 \mathrm{~V}$. The height of the berm can be raised to an additional height level with a slope of $(3 \mathrm{H}: 1 \mathrm{~V})$ when the waste that is deposited in the cells of a landfill and behind the berm reach the allowable maximum height of the berm [63]. The berm's layers profile has a similar composition to that of the base liner layers of the landfill (beneath the surface) with a slope of $(3 \mathrm{H}: 1 \mathrm{~V})$, or it is constructed from sandy soil [59].

On the berm, the anchor trench and the drainage ditch are constructed in a continuous line around the outside edge of the perimeter berm. In addition, the internal roads are constructed on the edge of the outside perimeter berm for the landfill $[20,59,61]$.

\subsection{Management of Stormwater}

Storm-water management at the landfill site contains run-on and run-off, and this should be taken into consideration to prevent contact of surface water with the waste mass to reduce leachate generation in the landfill $[60,75]$.

For the water run-on control system on a site, the drainage ditch should be constructed around the outside perimeter (at one edge) of the landfill to prevent rainfall water entering the site by means of collecting the storm-water from neighboring areas of the landfill [74-76]. The berms and outside drainage ditch are necessary to prevent storm-water from entering the landfill site facility and to reduce the quantity of leachate in situ. The shape and dimension of the ditch are constructed based on the amount of rainfall in the study area. Then, the collected water is sent to a storm water management pond $[74,75]$.

The run-off control system should have diversion ditches constructed on the surface and sides of the final cover for each cell in the landfill. The landfill surface and its sides should be given a suitable slope so that the top view of the landfill surface appears like ripples. The diversion ditches are used to divert the storm-water run-off to the lower drainage ditch. A lower drainage ditch is constructed around the landfill perimeter to collect water and gives an appropriate slope. The collected water (uncontaminated) should be sent to the storm-water management pond to allow sediment to settle by gravity before discharging it to the land surrounding the landfill or using it for other purposes $[60,77]$.

Diverting the storm-water runoff of leads to a reduction the amount of water entering the landfill from the surface and prevents it from coming into contact with the waste mass. This process acts to decrease leachate generation in the landfill, thus preventing groundwater pollution by the leachate $[74$, 77].

Any storm-water that infiltrates from the surface of the final cover, as well as any leachate that has percolated through the landfill layers, can be removed using the leachate collection pipes. Then, the collected leachate is sent to a leachate storage pond or other 
treatment facilities [75].

\subsection{Dust}

On a landfill site, dust is generated from the different operations within the site, especially during the dry season (when there is no rainfall). The sources of dust are unpaved road surfaces, the stockpile of soils and the dust that is released by the movement of various machines on site $[25,78]$.

For controlling dust emissions at a landfill site, many suggested steps can be adopted [21, 25, 78]. One recommendation is to cover the surface of internal roads at landfill sites with gravel material from the scales to the working area or pavement and add a thin layer of asphalt. On a landfill site, some waste materials can be used on the top surface of the waste mass to minimize the level of dust (e.g. construction concrete rubble, rubber, wood pieces and other materials that have a low content of fine particles). The maximum speed for the trucks inside the site should be determined, especially on unpaved roads, to reduce the quantity of dust raised. All roads inside the site (especially the unpaved roads) should be wetted by adding water in regular quantities to reduce the amount of dust released into the air during the dry periods.

\subsection{Leachate Storage Ponds}

The main technologies for leachate treatment in a landfill are physical, chemical and biological processes. The biological method is the most popular process for treating leachate in landfills in arid or semi-arid regions. The methods for the biological treatment of leachate include anaerobic and aerobic processes [66]. A pond of leachate retention should have a suitable capacity to receive the collected leachate from the landfill [23].

Evaporation is considered one of the simplest methods to treat leachate within lined ponds. The liner system in the ponds is like the liner system within the base liner system in landfills and includes a geomembrane liner and a bottom barrier layer to inhibit groundwater pollution by the leachate [79]. The leachate is collected from the waste and transferred through the leachate collection pipes to the leachate collection pond. Floating aerators are utilized in the leachate collection pond. These are used to prevent the anaerobic process in the ponds and minimize odors. The sludge must be removed from the bottom of the pond periodically and deposited either in the landfill cell(s) or transported to a site that must be approved by the responsible authorities [79].

In an arid climate, during the summer months, the leachate will be lost through evaporation from the leachate collection pond due to the increase in temperature (no rainfall). The leachate collection pond is distinguished by a large surface area and shallow depth. Therefore, during the summer months in an arid or semi-arid climate, a closed system to treat the leachate should be adopted [20]. To avoid the impact of adverse odor that results from the anaerobic process during the winter months, surface aerators should be installed. These are used to oxygenate the leachate depending on the size of the leachate collection pond and the amount of leachate in the pond [20].

\subsection{Treatment Methods for Collected Leachates}

The common methods to treat the leachate in the leachate collection ponds are anaerobic, aerobic and semi-aerobic:

\subsubsection{Anaerobic Method}

The anaerobic method is used to remove the heavy metals in rainfall from the leachate and transform them into carbonates [66]. In the anaerobic process, excess sludge is produced, requiring little management, and the compounds of complex organics are transformed into $\mathrm{CH}_{4}$ and $\mathrm{CO}_{2}[66,80]$. The products of anaerobic decomposition usually have a high concentration of BOD, as well as inflammable gases such as methane $\left(\mathrm{CH}_{4}\right)$. In addition, malodorous gases like sulfurous oxides $\left(\mathrm{SO}_{\mathrm{x}}\right)$, hydrogen sulphide $\left(\mathrm{H}_{2} \mathrm{~S}\right)$ and nitrous oxides (NOx) are produced [81].

\subsubsection{Aerobic Process}

In the aerobic method, oxygen is required to 
transform organic nitrogen into ammonia (by oxidation). Then, the activity of nitrite-oxidizing bacteria converts ammonia into nitrate nitrogen (NO3-N) (stabilized state). Generally, solid waste decomposition using an aerobic process is faster than decomposition by an anaerobic process. The outputs of the aerobic decomposition process consist of simple materials (without odors) (e.g. water, $\mathrm{CO}_{2}$ and $\mathrm{HNO}_{3}$ ) [81] .

\subsubsection{Semi-aerobic Method}

The semi-aerobic method is used in landfill to increase the microbial activity level when oxygen is present to increase the rate of waste decomposition and stabilize waste settlement faster. The semi-aerobic process intends to improve the leachate quality and significantly minimize the emission of gases such as methane and hydrogen sulphide [81].

In the early $1970 \mathrm{~s}$, the semi-aerobic process was developed by Fukuoka City and Fukuoka University in Japan (as a joint project). In 1975, the first test for the semi-aerobic method was conducted at Shin-Kamata landfill in Fukuoka, Japan, and it showed good results [81].

The collected leachate is removed to the leachate collection pond quickly using perforated pipes. The main drain pipes and the main header pipe for collecting the leachate are always open to the air from the outlet to the pond. Usually, one third of the section of these pipes is filled with leachate, and the rest of the section is left for airflow. In addition, the vertical gas ventilation pipes are installed at every intersection of the main collection pipe with the lateral pipes and also at the ends of the lateral pipes and the main collection pipes. This allows fresh air to enter the waste layer and provide aerobic conditions, increasing the microbial activity and helping to accelerate waste decomposition [81]. The temperature inside the landfill (resulting from microbial activity due to the semi-aerobic method) is higher than the air temperature outside the landfill. The different temperature between inside and outside the landfill allows air to enter the waste mass through main drainpipes and the main header pipe [81].

\subsection{Gas Vent System}

The gas vent pipes are installed in a landfill over the main collection pipe at every intersection (manhole), with the lateral pipes also over the two lateral pipes in the manhole (at the sump). Each main collection pipe is connected by a series of lateral pipes on both sides [23, 82]. The gas vent pipes are perforated and preferably made from HDPE with a diameter of $15 \mathrm{~cm}$. The vent pipes are placed in a cylindrical cage with a diameter of $75 \mathrm{~cm}$ made from strong mesh wire and surrounded by gravel or boulders, which is packed into the cylinder [23].

The gas vent system is used to reduce the negative effects of gases on human health and the surrounding environment. In addition, it contributes to stabilizing the waste mass through increasing the process of decomposition of organic materials within it [23]. Preventing the ingress of water into the gas pipes vents should be taken into consideration in the design of the gas vents system [24]. The gas vents system that is installed on leachate collection pipes should be connected to the passive flare system when the quality of gas is very low or connected with the gas collection and control system if it contains high concentrations of gases [83].

\subsection{Gas Management System}

Waste biodegradation produces gas within the landfill. In the landfill site, the collected gas should either be treated and utilized to produce energy or vented to a flare system if the quality of gas is insufficient to generate energy [84]. Designers usually recommend installing barriers with low-permeability in the liner base system and final cover for landfills to minimize the gas emissions from the landfill or within the landfill layers [58]. Gas can be collected from a landfill by installing an extraction gas system within the waste zone or the gas collection layer. There are two types of gas extraction system: a passive gas drainage system (for small sites) and an active extraction system (for large sites) [58]. 
In active systems, the gas is extracted by vacuum and pumped to a place where energy can be recovered, or it can be burned off as a flare. In active gas systems, the gas collection and control system units are the extraction wells (vertical and horizontal), wellheads, the lateral and header pipes, the condensate system, the blower system and flares system [82]. In passive gas systems, the gas is transferred under different atmospheric pressure. The gas can be vented to the passive flare or by using the gas treatment system [82]. When using the passive venting system, untreated gas should be prevented from entering the atmosphere [58].

\subsection{General Landfill Facilities}

The landfill design should include the facilities which are necessary for solid waste management inside the sites of landfill and to provide comfortable conditions to staff in the sites. The facilities that should be considered in the landfill are [21, 23, 64]:

- Main access road to the landfill and internal roads in site.

- Perimeter fence (e.g. wire fence) with main gate to be used to prevent persons, which do not have authorization to come inside a site of landfill to pick waste and to prohibit entry of animals.

- Scale bridge should be constructed to weigh trucks to provide the accurate electronically data for the quantity of waste that is received in the sites of the landfill.

- Administration building is constructed for the operation personnel of the landfill.

- Workshop to be used for service and maintenance.

- Guard house for controlling the site.

- Garages is built for accommodating machineries and equipment.

- Others (e.g. vehicles cleaning, parking areas, weather station and so on).

\subsection{The HELP $3.95 \mathrm{D}$ Model}

For checking the suggested design of landfill for selected new sites in the arid areas (Babylon
Governorate, as a case study), the model of hydrologic evaluation of landfill performance (HELP 3.95 D) was used. The HELP model is the most widely applied throughout the world for the last 30 years, where it is used to analysis the hydrological water balance in landfills. In addition, this model is applied to estimate the leachate quantity through the bottom barrier layer as well as the amount of water infiltrated through the final cover layers for landfills [12]. The HELP model was presented in 1982 by Paul Schroeder through the U.S. Army Corps of Engineers at the Waterways Experiment Station, Vicksburg, Mississippi, and the US Environmental Protection Agency. The latest version of the HELP 3.95 D was developed by Berger and Schroeder [13].

The HELP model is known as a "quasi-two dimensional" model because this model deals with many hydrologic processes that have one dimensional, in two directions. For Example, in the HELP model, the vertical flow (evapotranspiration and infiltration) and the lateral flow (surface runoff, lateral drainage) are calculated, but no calculated as a two-dimensional flow [12].

Weather parameters as well as soil and design data were entered into the HELP model to calculate the amounts of potential and actual evapotranspiration, runoff, lateral drainage of leachate and percolation leachate through the barrier liners in the landfill with high ability $[4,14]$.

\subsubsection{Leachate}

A water balance process is the most prevalent method for building the perfect model to calculate the rate of leachate in landfills. This process is based on estimating the amount of inflows and outflows of water in soil layers in a specific area [85].

Leachate is defined as the amount of contaminant liquids resulted from different processes (e.g. chemical, physical, and microbial). The leachate at a landfill is percolated from the waste zone through the layers of soil, thereby this causes soil and groundwater pollution [67]. The amount of leachate that is formed in a landfill 
is affected by many factors [59]. The first factor includes precipitation $(\mathrm{P})$ that represents the water flows in soil layers. The factors of runoff (R) and evapotranspiration (ET) are defined as the water movement outside soil layers. The WC is water content of the deposited waste as well the factor of the change in water storage through the soil $(\Delta \mathrm{S})$ [85]. The quantity of leachate generated can be estimated using the following Eq. (7) [86].

$$
\mathrm{L}=\mathrm{P}-\mathrm{ET}-\mathrm{R}+\mathrm{WC}-\Delta \mathrm{S}
$$

where, $\mathrm{L}$ is the amount of leachate; $\mathrm{P}$ is precipitation; ET is evapotranspiration; $\mathrm{R}$ is water runoff; $\mathrm{WC}$ is water content of the deposited waste; $\Delta \mathrm{S}$ is water storage in the soil.

2.13.2 Input Required Data in the HELP Model
The required input data in the HELP model can be divided into three main groups. These groups are daily weather data for complete calendar of selected years, the needed data for estimating the evapotranspiration value as well as soil layers' data for landfill design. In this study, all data that input in this model were in metric units [13]. In the current study, daily depths of precipitation, daily averages of temperature and daily sum of solar radiation for 12 consecutive years (2005-2016) [35] were entered into the HELP model as text files (Table 9).

The required input data to calculate the potential and actual evapotranspiration, runoff curve number and the data of soil and solid waste in the HELP model can be seen in Table 10.

Table 9 Average annual data of weather parameters for the years (2005-2016) in Babylon Governorate.

\begin{tabular}{lllllllllllll}
\hline Parameters & 2005 & 2006 & 2007 & 2008 & 2009 & 2010 & 2011 & 2012 & 2013 & 2014 & 2015 & 2016 \\
\hline $\begin{array}{l}\text { Daily depth rainfall } \\
(\mathrm{mm})\end{array}$ & 73.2 & 170.3 & 41 & 51.8 & 52.4 & 87.3 & 41.7 & 128.8 & 182.9 & 125 & 133.4 & 135.4 \\
$\begin{array}{l}\text { Daily mean } \\
\text { temperature }\left({ }^{\circ} \mathrm{C}\right)\end{array}$ & 23.1 & 23.5 & 23.5 & 23.6 & 23.9 & 23.6 & 23.2 & 24.1 & 23.3 & 24.2 & 24.6 & 24.5 \\
$\begin{array}{l}\text { Daily sum solar } \\
\text { radiation }\left(\mathrm{MJ} / \mathrm{m}^{2}\right)\end{array}$ & 5,630 & 5,638 & 5,636 & 5,673 & 5,643 & 5,628 & 5,628 & 5,702 & 5,647 & 5,639 & 5,736 & 5,729 \\
\hline
\end{tabular}

Table 10 The required data to calculate potential and actual evapotranspiration, runoff curve number and soil and solid waste data in the HELP model.

\begin{tabular}{|c|c|c|c|}
\hline No. & Parameters & Required data & Reference \\
\hline \multicolumn{4}{|c|}{ Potential and actual evapotranspiration } \\
\hline 1 & Geographic latitude & 32.5 & \\
\hline 2 & The depth of the evaporative zone & $50 \mathrm{~cm}$ & Field tests \\
\hline 3 & $\begin{array}{l}\text { The start and end days of the growing season over the } 12 \\
\text { years }\end{array}$ & 10th January-15t $\mathrm{t}^{\mathrm{h}}$ December (350 days) & {$[35]$} \\
\hline 4 & Leaf area index $(\mathrm{LAI})$ & 1 & [13] \\
\hline 5 & The annual average wind speed at $2 \mathrm{~m}$ above the ground & $7.2 \mathrm{~km} / \mathrm{h}$ & {$[34]$} \\
\hline 6 & The average values of relative humidity for the four quarters & $\begin{array}{l}64.2 \% \text { (first quarter), } 39.03 \% \text { (second quarter), } \\
34.24 \% \text { (third quarter), } 60.95 \% \text { (fourth quarter) }\end{array}$ & {$[34]$} \\
\hline \multicolumn{4}{|c|}{ Runoff curve number $=87.83 \%$} \\
\hline 1 & Soil texture type & Top soil (silty clay loam) & \\
\hline 2 & Maximum leaf area index & Fair grass & {$[13]$} \\
\hline 3 & Slope of surface & $3 \%$ & \\
\hline 4 & The length of slope & $100 \mathrm{~m}$ & \\
\hline \multicolumn{4}{|c|}{ The data of soil and solid waste } \\
\hline 1 & Soil texture & - & {$[13]$} \\
\hline 2 & Layer type & $\begin{array}{l}\text { Vertical percolation (VPL), lateral drainage (LDL), } \\
\text { Barrier soil liners (BSL), geomembrane liner (GL) }\end{array}$ & {$[85]$} \\
\hline 3 & Layer thickness & $\mathrm{cm}$ & {$[13]$} \\
\hline 4 & Saturated hydraulic conductivity & $\mathrm{cm} / \mathrm{s}$ & [13] \\
\hline 5 & Moisture content, wilting point, porosity and field capacity & vol./vol. & {$[13]$} \\
\hline
\end{tabular}


2.13.3 Checking Suggested Landfill Design Using the HELP Model

In HELP model, the base liner system components for suggested landfill design (from the bottom to the top layers) consist of bottom barrier layer, geomembrane, leachate collection system and protection layer. The components of suggested layers for the final cover system (from the bottom toward the top layers) are: intermediate cover layer, foundation layer, top barrier layer, geomembrane, support vegetation layer and topsoil layer. Table 11 shows the characteristics of proposed soil layers that entered into the HELP model. The sketch for suggested landfill design that entered in the model can be seen in Fig. 8.

Table 11 Characteristics of suggested soil layers data in the HELP model [15].

\begin{tabular}{|c|c|c|c|c|c|c|c|c|}
\hline No. & Type & Material & $\begin{array}{l}\text { Thickness } \\
(\mathrm{cm})\end{array}$ & $\begin{array}{l}\text { Porosity } \\
\text { (vol./vol.) }\end{array}$ & $\begin{array}{l}\text { Field capacity } \\
\text { (vol./vol.) }\end{array}$ & $\begin{array}{l}\text { Wilting point } \\
\text { (vol./vol.) }\end{array}$ & $\begin{array}{l}\text { Initial water } \\
\text { content (vol./vol.) }\end{array}$ & $\begin{array}{l}\text { Hydraulic } \\
\text { conductivity }(\mathrm{cm} / \mathrm{sec})\end{array}$ \\
\hline 1 & $\mathrm{VPL}^{\mathrm{a}}$ & $\begin{array}{l}\text { Top soil layer (silty } \\
\text { clay loam) }\end{array}$ & 15 & 0.471 & 0.342 & 0.210 & 0.214 & $4.0 \mathrm{E}-5$ \\
\hline 2 & VPL & $\begin{array}{l}\text { Support vegetation } \\
\text { layer }\left(\mathrm{MC}^{\mathrm{b}} \text { loam }\right)\end{array}$ & 45 & 0.419 & 0.307 & 0.180 & 0.234 & $1.0 \mathrm{E}-5$ \\
\hline 3 & $\begin{array}{l}\mathrm{GM}^{\mathrm{c}} \\
\left(\mathrm{FML}^{\mathrm{d}}\right)\end{array}$ & $\begin{array}{l}\text { Geomembrane liner } \\
\left(\mathrm{HDPE}^{\mathrm{e}}\right)\end{array}$ & 0.5 & \multicolumn{4}{|c|}{ Drainage slope $3 \%$; Drainage length $100 \mathrm{~m}$} & $2.0 \mathrm{E}-13$ \\
\hline 4 & $\mathrm{BSL}^{\mathrm{f}}$ & $\begin{array}{l}\text { Top barrier ( } \mathrm{HC}^{\mathrm{g}} \\
\text { sandy clay) }\end{array}$ & 45 & 0.40 & 0.366 & 0.288 & 0.40 & $1.0 \mathrm{E}-7$ \\
\hline 5 & VPL & $\begin{array}{l}\text { Foundation layer } \\
\text { (coarse sand) }\end{array}$ & 30 & 0.417 & 0.045 & 0.018 & 0.045 & $1.0 \mathrm{E}-2$ \\
\hline 6 & VPL & $\begin{array}{l}\text { Intermediate cover } \\
\text { (MC silty clay loam) }\end{array}$ & 30 & 0.445 & 0.393 & 0.277 & 0.393 & $1.0 \mathrm{E}-6$ \\
\hline 7 & VPL & $\begin{array}{l}\text { Compacted waste } \\
\left(700 \mathrm{~kg} / \mathrm{m}^{3}\right)\end{array}$ & 200 & 0.61 & 0.161 & 0.077 & 0.161 & $1.0 \mathrm{E}-5$ \\
\hline 8 & VPL & $\begin{array}{l}\text { Protective layer } \\
\text { (sand) }\end{array}$ & 30 & 0.437 & 0.062 & 0.024 & 0.062 & $5.0 \mathrm{E}-3$ \\
\hline 9 & $\mathrm{LDL}^{\mathrm{h}}$ & $\begin{array}{l}\text { Drainage blanket } \\
\text { layer (gravel) }\end{array}$ & 30 & 0.397 & 0.032 & 0.013 & 0.032 & $3.0 \mathrm{E}-1$ \\
\hline 10 & $\begin{array}{l}\text { GM } \\
\text { (FML) }\end{array}$ & $\begin{array}{l}\text { Geomembrane liner } \\
\text { (HDPE) }\end{array}$ & 0.15 & \multicolumn{4}{|c|}{ Drainage slope $3 \%$; Drainage length $100 \mathrm{~m}$} & $2.0 \mathrm{E}-13$ \\
\hline 11 & BSL & $\begin{array}{l}\text { Bottom barrier (HC } \\
\text { sandy clay) }\end{array}$ & 60 & 0.40 & 0.366 & 0.288 & 0.40 & $1.0 \mathrm{E}-7$ \\
\hline
\end{tabular}

a VPL: vertical percolation layer; ${ }^{\mathrm{b}} \mathrm{MC}$ : moderate compacted; ${ }^{\mathrm{c}} \mathrm{GM}$ : geomembrane; ${ }^{\mathrm{d}} \mathrm{FML}$ : flexible membrane liner; ${ }^{\mathrm{e}} \mathrm{HDPE}$ : high density polyethylene; ${ }^{\mathrm{f}} \mathrm{BSL}$ : composite barrier soil; ${ }^{\mathrm{g}} \mathrm{HC}$ : high compacted; ${ }^{\mathrm{h}} \mathrm{LDL}$ : lateral drainage layer.

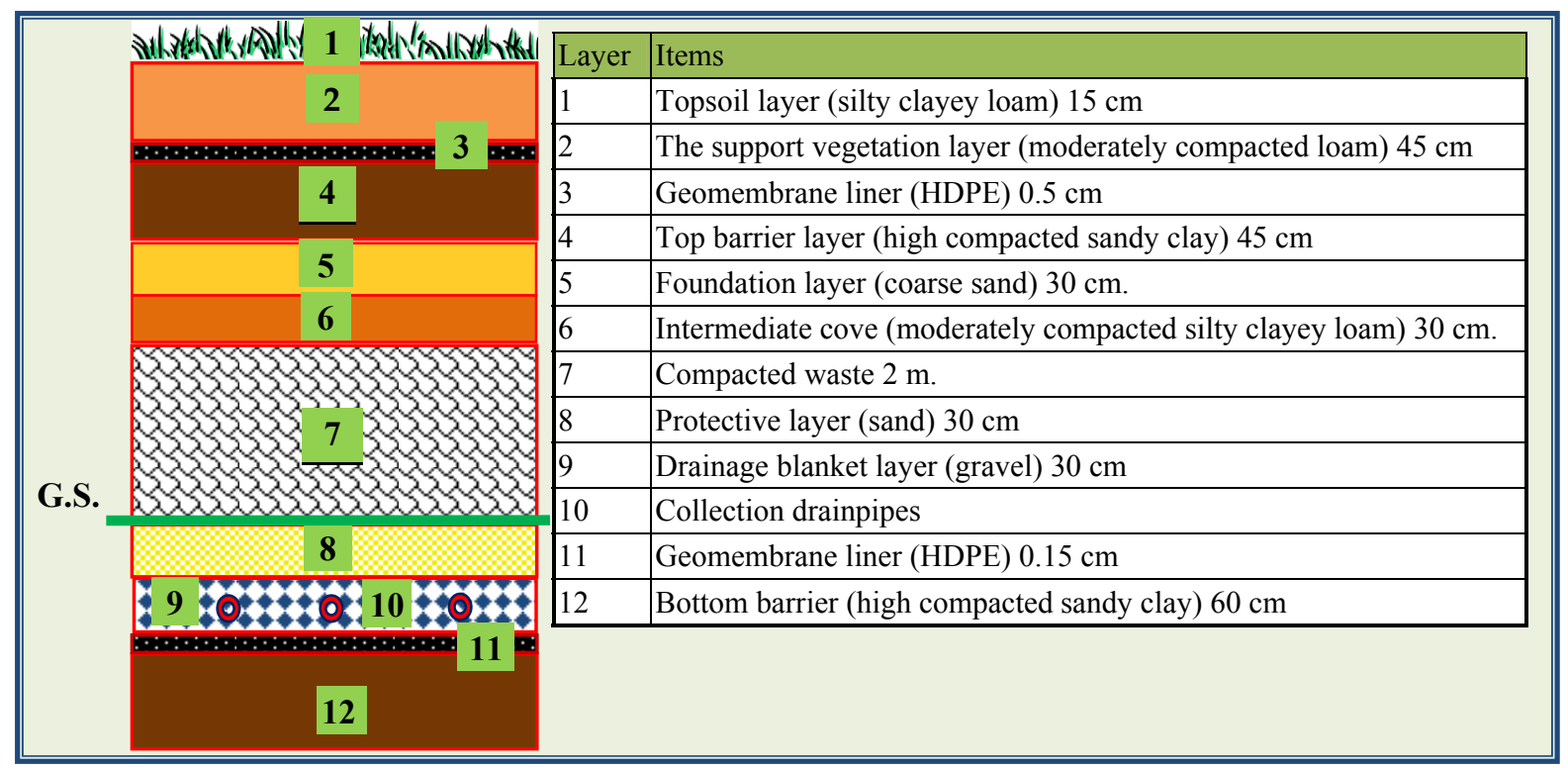

Fig. 8 Sketch of the suggested soil layer for landfill entered in the HELP model [15]. 


\section{Results}

To check the suggested soil layers that were used for landfill design in Babylon governorate (in the arid area), the HELP model was used for this purpose. For the suggested landfill design, hydrological parameters and required information for soil layers were given as an input into the HELP model. Then, the extension files for these parameters were created within the model. The results of proposed design for the selected landfills in Babylon governorate are as follow:

\subsection{Annual Readings Results for the Suggested Landfill Design}

Annual results' readings for the suggested landfill design for selected years (2005-2016) were calculated in the HELP model as follows:

- The amount of collected water from drainage layer (9) was zero.

- The average water head values over the geomembrane surface for layers 3 and 10 were equal to zero.

- The values of water leakage through the composite barrier soil (layers 4 and 11) were zero.

The annual readings results for the suggested landfill design showed that there was no water percolation through the suggested soil layers of the base liner system (under the ground surface).

In the HELP model, within the final cover system of landfill, the values of water above geomembrane (layer 3) for the years from 2013 to 2016 were 99.2, 99.8, 99.6 and $99.3 \mathrm{~mm}$ respectively. The water amount that infiltrated through the top barrier (layer 4) had same values of $0.03 \mathrm{~mm}$ for the years from 2013 to 2016 . These values came from the cumulative amount of rainfall that fell in Babylon Governorate starting from the year 2012 to 2016 .

In the HELP model, the annual distribution of the weather parameters for the years from 2005 to 2016 on the selected sites was computed. The amount of rainfall equals the runoff, actual evapotranspiration and change in soil water content.

In this model, the first value of rainfall in 2005 (40 $\mathrm{mm}$ ) was added to the initial water content in the soil layers of $987.84 \mathrm{~mm}$. Therefore, the value of soil water content at the starting of year 2005 was $1,027.84 \mathrm{~mm}$. The amount of soil water storage for all layers at the end of each year was computed in the HELP model based on the values of the hydrological parameters in the study area, where these values contributed to the water storage change in total soil layers. For instance, the value of soil water storage at the start of the year 2016 was $1,076.62 \mathrm{~mm}$. The value of soil water storage change in 2016 was $-10.15 \mathrm{~mm}$. This value led to change the value of soil water storage for all layers at the end of year 2016 to be $1,066.47 \mathrm{~mm}$. The value of $38.63 \mathrm{~mm}$ resulted from the different between final and initial of soil water storage at the end year of 2016 $(1,066.47 \mathrm{~mm})$ and year of $2005(1,027.84 \mathrm{~mm})$. The results of annual readings for the hydrological water balance in the selected sites for landfill in Babylon Governorate for each year from 2005 to 2016 that were computed in the current model, can be seen in Table 12.

The values of soil water content at the end of each year from 2005 to 2016 are shown in Fig. 9. The soil water content at starting year of 2005 was $1,027.84$ $\mathrm{mm}$.

\subsection{Results of Maximum Daily Readings for the Suggested Landfill Design}

The maximum daily values were calculated in the HELP model for the water behavior in the suggested soil layers and for the different hydrological parameters through the selected years from 2005 to 2016. The maximum daily reading during the selected period (2005-2016) for the water leakage through the top barrier soil (layer 4) was $1.4 \times 10^{-4} \mathrm{~mm}$, and 156.6 $\mathrm{mm}$ for average water level above the geomembrane surface (layer 3). All maximum daily readings for the drainage water collected from drainage (layer 9), average water level over the geomembrane surface 
Table 12 Annual data for the hydrological water balance for the selected period (2005-2016).

\begin{tabular}{lllllllllllll}
\hline Items & 2005 & 2006 & 2007 & 2008 & 2009 & 2010 & 2011 & 2012 & 2013 & 2014 & 2015 & 2016 \\
\hline Rainfall & 73.2 & 170.3 & 41 & 51.8 & 52.4 & 87.3 & 41.7 & 128.8 & 182.9 & 125 & 133.4 & 135.4 \\
Runoff & 1.59 & 1.82 & 0 & 0 & 0 & 0 & 0 & 41.6 & 66.27 & 1.59 & 3.89 & 12.17 \\
AET & 71.54 & 127.41 & 79.27 & 47.93 & 42.83 & 87.89 & 57.0 & 24.31 & 135.58 & 128.41 & 120.61 & 133.38 \\
S.W.S.C. & 0.07 & 41.07 & -8.27 & 4.41 & 9.57 & -0.59 & -15.3 & 62.89 & -18.95 & -5.0 & 8.9 & -10.15 \\
\hline
\end{tabular}

AET.: actual evapotranspiration; S.W.S.C.: soil water storage change.

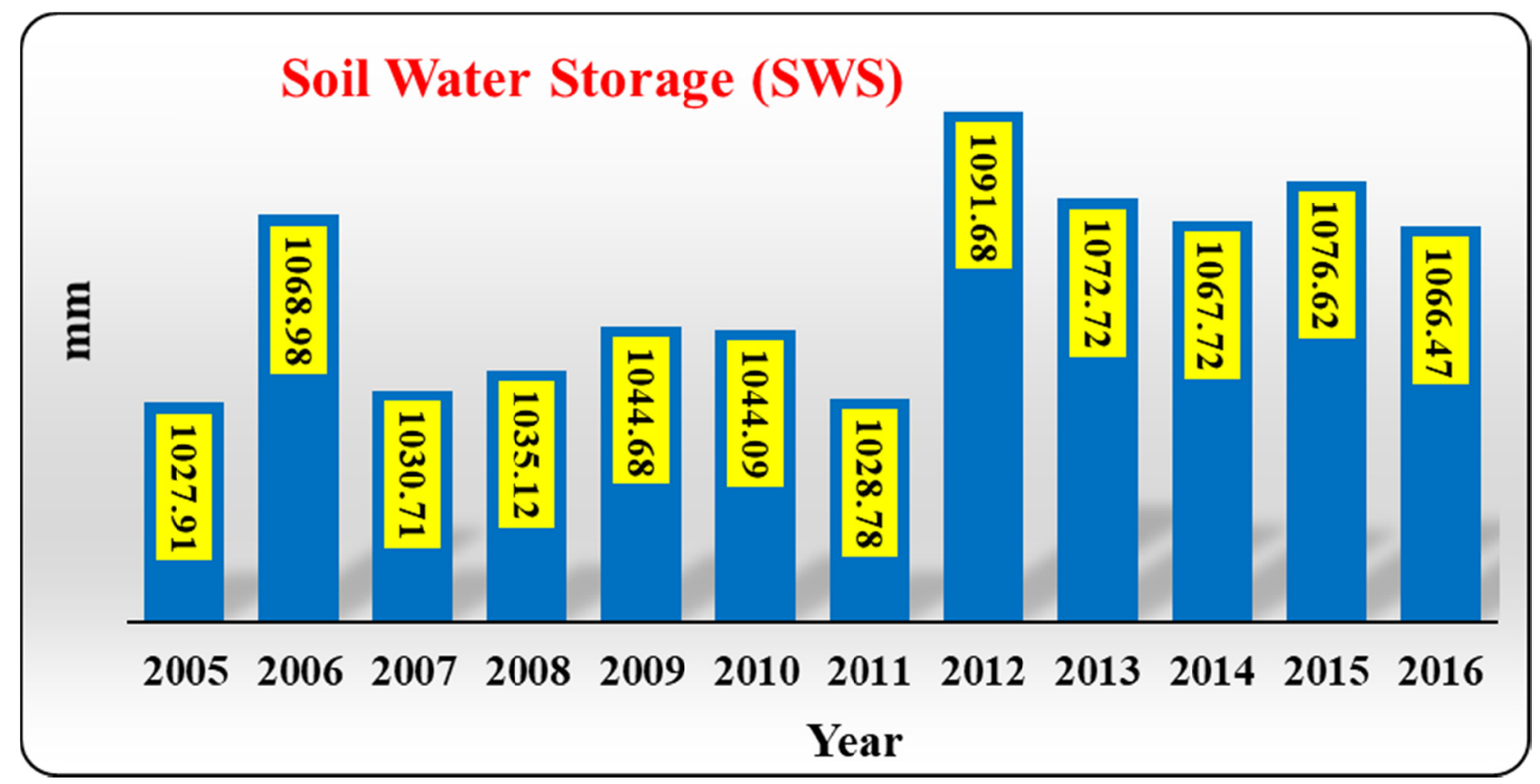

Fig. 9 Annual values of SWS (soil water storage) for each year from 2005 to 2016.

(layer 10) and leachate percolation amount through bottom barrier soil (layer 11) were equal to zero. According to McEnroe's equations [87], the water level on layers' surface was computed.

\subsection{Average Monthly Readings Results for the} Suggested Landfill Design

The average monthly reading of the water status and behavior within the soil layers for the suggested landfill design that were calculated in the HELP model for the years (2005-2016) are as follow:

- The lateral drainage amount that collected the water from the layer (9) was zero.

- The value of water level value over the surface of geomembrane (layer 10) was zero.

- The value of water percolation through the bottom barrier (layer 11) was equal to zero.
Table 13 shows the results of water infiltrated through the top barrier (layer 4), and the water level over the surface of geomembrane (layer 3 ) within the final cover system of landfill.

\subsection{Average Annual Readings Results for the Suggested Landfill Design}

In the current model, the average annual values $(\mathrm{mm})$, and their proportions were calculated in the HELP model for the years (2005-2016). The lateral drainage of water collected from layer (9) was zero. The value of leachate percolated through the bottom barrier (layer 11) was zero, while it was $0.01 \mathrm{~mm}$ through the top barrier (layer 4 ). The average water level on the surface of geomembrane (layer 3) was 33.2 $\mathrm{mm}$, while it was equal to zero over the geomembrane surface (layer 10). 
Table 13 Average monthly data $(\mathrm{mm})$ for the years (2005-2016).

\begin{tabular}{lllllll}
\hline Items & Jan. & Feb. & Mar. & Apr. & May & Jun. \\
\hline Water percolation through layer $(4)\left(\times 10^{3}\right)$ & 0.7 & 0.9 & 1.1 & 1.0 & 0.9 & 0.9 \\
Averages water head on top of layer (3) & 2.5 & 3.3 & 3.8 & 3.6 & 3.3 & 3.3 \\
Items & Jul. & Aug. & Sep. & Oct. & Nov. & Dec. \\
Water percolation through layer $(4)\left(\times 10^{3}\right)$ & 0.9 & 0.9 & 0.9 & 0.9 & 0.9 & 0.9 \\
Averages water head on top of layer (3) & 3.3 & 3.3 & 3.3 & 3.3 & 3.3 & 3.3 \\
\hline
\end{tabular}

Table 14 Initial and final water storage in all soil layers in the starting year of 2005 and at the end year of 2016, as well as volumetric change.

\begin{tabular}{llll}
\hline Layer & Initial water storage $(\mathrm{mm})$ & Final water storage $(\mathrm{mm})$ & Volumetric change (vol./vol.) \\
\hline 1 & 32.15 & 51.76 & 0.1308 \\
2 & 94.09 & 112.98 & 0.042 \\
3 & 0.0 & 0.0 & 0 \\
4 & 180 & 180.0 & 0 \\
5 & 13.5 & 13.5 & 0 \\
6 & 117.9 & 117.9 & 0 \\
7 & 322 & 322.13 & 0.0001 \\
8 & 18.6 & 18.6 & 0 \\
9 & 9.6 & 9.6 & 0 \\
10 & 0.0 & 0.0 & 0 \\
11 & 240 & 240.0 & 0 \\
\hline
\end{tabular}

In the HELP model, the average annual values during the years 2005-2016 for the amounts of runoff, actual evapotranspiration and change in water storage in the soils were $10.74 \mathrm{~mm}(10.54 \%), 87.97 \mathrm{~mm}(86.30 \%)$ and $3.22 \mathrm{~mm}(3.16 \%)$ respectively.

\subsection{Water Storage Behavior for the Suggested Soil Layers in Landfills}

The values of initial soil water storage in the starting year of 2005 and final soil water storage at the end of the year 2016 for all suggested layers for landfill with volumetric change between initial and final water storage were calculated in the HELP model.

\section{Discussion}

This study dealt with the suggested design for landfill in arid areas and Babylon governorate in Iraq was selected as a case study. The groundwater depth in Babylon Governorate is shallow. So, this problem was taken into consideration when selecting the sites and designing the landfills. The most important criteria were selected to determine the best sites for landfill. These criteria can be applied in arid areas with shallow groundwater depths.

The suggested design of landfill comprises the soil layers of the base liner system and the final cover system. The base liner system consists of the composite bottom barrier layer of high compacted sandy clay with hydraulic conductivity of $1.0 \mathrm{E}-7 \mathrm{~cm} / \mathrm{s}$ rather than clay liner, to avoid cracks in this layer [58]. For the composite bottom layer, the mixture proportions of Green clay (70\%) and Red clay (80\%) with sand gave hydraulic conductivity of $1.0 \mathrm{E}-11 \mathrm{~cm} / \mathrm{s}$. These types of clay (Green and Red) are available in Iraq [18].

The geomembrane liner was placed over the barrier layer to increase the efficiency of the bottom layer by reducing the migration of pollutants toward the groundwater. The leachate collection system consists of drainage layer of gravel with thickness of $30 \mathrm{~cm}$. This system is used to remove the leachate by collection pipes. The protection layer consists of sand, 
and its hydraulic conductivity is $5.0 \mathrm{E}-3 \mathrm{~cm} / \mathrm{s}$. The thickness of this layer is $30 \mathrm{~cm}$. This layer is used to inhibit fine waste particles from transferring into the drainage layer and prevent clogging it $[8,24]$.

In the current design, the final cover system "Recommended design" was adopted. This was achieved by combining the positive properties for certain soil layers from "RCRA Subtitle D" "Evapotranspiration (ET), (capillary barriers type)". The principle of the "Recommended design" for the final cover system layers in landfill in this study depend on the effects weather parameters in the arid areas. The purpose of using the final cover is to prevent infiltrated water from the surface to enter the waste body. Consequently, the amount of leachate generated toward the lower layers in landfill will be minimized [15].

The intermediate soil should be used to cover the waste body as an essential layer for a specific period to reduce the risks on the environment and human health from the negative impacts. Furthermore, the soil cover is necessary to be used during the period of decomposition of the organic materials within the waste zone to fill the subsidence areas on the surface, as well as to avoid the cracks in the top barrier layer.

The foundation layer represents a cushion for the engineering system of final cover layers against damage, and it acts as a filter for fine particles. This layer consists of coarse sand with thickness of $30 \mathrm{~cm}$, and its hydraulic conductivity is $1.0 \mathrm{E}-2 \mathrm{~cm} / \mathrm{s}$. The gas collection system is installed within the foundation layer over the waste zone.

The composite top barrier and the geomembrane liner (HDPE) is to prevent water that infiltrated from the surface to flow through into the waste body until it evaporates due to the high temperature during the most months in the arid area. Therefore, these layers act to decrease the amount of leachate percolation from the waste zone toward the lower layers of the base liner system.
The clay layer (low-permeability) that is used as a barrier layer in landfill is difficult to implement and maintain. The clay layer is exposed to cracking due to the decomposition of the organic materials within the waste body (under clay layer) causing differential settlement at the layer surface that cover the waste. In addition, the clay layer is exposed to drying due to expected high evaporation rates from soil surface of landfill [58]. The purpose of mixing soils' materials in the barrier layer is to reduce potential of swell and shrinkage, and improving of shear strength of the cohesive clayey soils. Mixing of these soils with granular materials (e.g. sand) is one of the methods of improving the soil properties $[18,88]$. Therefore, in the current design, the composite barrier was used within the final cover system to avoid the cracks in this layer. Ref. [18] found that the sandy clay is suitable to be used as a top barrier for the cover system in the landfill. The mixture proportions of $30-50 \%$ Green clay with sand and $40-60 \%$ of Red clay with sand gave a hydraulic conductivity of $1.0 \mathrm{E}-9$ to $1.0 \mathrm{E}-10 \mathrm{~m} / \mathrm{sec}$. To protect the barrier layer from cracks that can result from high temperature and conserve the water saturation level in the layer, the waterproof or geomembrane liner should be used to cover the barrier layer [58].

The materials to support the vegetation layer (45-60 $\mathrm{cm})$ and the topsoil layer $(15 \mathrm{~cm})$ will reduce the potential of surface erosion of landfill by runoff. This is achieved through storing the infiltrated water until it evaporates. The materials of these layers are available locally in Babylon Governorate. The support vegetation consists of moderate compacted loam with hydraulic conductivity of $1.0 \mathrm{E}-5 \mathrm{~cm} / \mathrm{s}$. The topsoil layer contains silty clayey loam materials with hydraulic conductivity of $4.0 \mathrm{E}-5 \mathrm{~cm} / \mathrm{s}$.

The suggested design of landfill for selected new sites for in the arid areas (Babylon Governorate) was checked using the model of HELP 3.95 D. In the suggested design, the soil layers and weather parameters for the years from 2005 to 2016 were 
entered into the HELP model. This model was used to calculate the amount of runoff, and actual evapotranspiration, lateral drainage of leachate and leachate percolation through the barrier layer in the landfill [14]. The HELP model usually gives overestimation for the quantity of the leachate more than the resultant actual leachate [4]. For the current landfill design, the HELP model was given an amount of leachate that is considered more safety for the designers when selecting the required thickness of layers and the type of soil materials, which used in these layers.

The results which were calculated by the HELP model for the studied period showed that the largest amount of water comes from precipitation. It was water evaporation is higher than the runoff (see Table 12). There was no water percolation through the suggested soil layers of the base liner system (under the ground surface). For the proposed design for the final cover system, the results showed that some amount of rainfall was infiltrated into the topsoil layer and the support vegetation layer, and it stopped above the top barrier layer. The water infiltrated was stored within the support vegetation layer and above the top barrier layers. In the HELP model, the amount of runoff on the surface during the years (2005-2016) was little. There was no water percolation from the geomembrane layer and the top barrier layer within the final cover system through the years from 2005 to 2012 . This is due to the fact that the hydrological the water balance in the suggested design of the landfill is affected by weather parameters of the study area. For the years from 2013 to 2016, there was so little amount of water leakage from the top barrier layer within the final cover system. This is due to the high amount of precipitation that fell in Babylon Governorate during these years that led to cumulative water storage in the soil layers. The amount of water that came from the surface percolated just into the waste zone, without any leakage through the layers of the base liner system (under the waste zone). In the HELP model, change in soil water storage at the end of the year 2016 for the suggested landfill design was $(-10.15 \mathrm{~mm})$. This means that the hydrological water balance in the studied area for the years (2005-2016) was negative.

For the suggested design of landfill, in the HELP model, the average annual amount of precipitation was $101.93 \mathrm{~mm}$. This value was distributed into actual evapotranspiration of $87.97 \mathrm{~mm}(86.30 \%)$ which represent a high value due to high temperature in the study area compared with the little amount of runoff of $10.74 \mathrm{~mm}$ (10.54\%). Although, the average water level over the geomembrane liner was $33.16 \mathrm{~mm}$, and the mean amount of water infiltrated through the top barrier was just $0.01 \mathrm{~mm}$, but there was no leachate percolation through the bottom barrier layer.

In the HELP model, the maximum daily values for precipitation and runoff (respectively) were $98.6 \mathrm{~mm}$ and $65.5 \mathrm{~mm}$ during the years from 2005 to 2016 . These values were recorded in November 2013. The maximum daily value of water level above the geomembrane liner was $156.6 \mathrm{~mm}$, and the amount of water percolated through the top barrier layer was $1.4 \mathrm{E}-4 \mathrm{~mm}$ (so little) into the waste body. In addition, the results showed that there was no leachate percolation beneath the waste zone through the layers of the base liner system.

For all layers, the difference between the initial water storage at the start of the year $2005(102.784 \mathrm{~cm})$ and the final soil storage at the end of the year 2016 $(106.647 \mathrm{~cm})$ was $3.863 \mathrm{~cm}$. In the suggested landfill design, the increase of the final water storage at the end year of 2016 was as a result of infiltrated surface water through the topsoil layer (1), the support vegetation layer (2) as well as from the little amount of water percolation through the waste body (layer 7). It should be mentioned however that there was no leachate percolation from any layers of the landfill positioned beneath the ground surface.

\section{Conclusions}

In the current study, the suggested design of landfill 
for arid areas included the base liner and final cover systems. The results showed there was no water percolation through the bottom barrier layer during the years (2005-2016) using the HELP model.

The suggested layers for the final cover system "Recommended design" were built through the combination of certain positive features from "RCRA Subtitle D” "Evapotranspiration soil cover (ET), (capillary barriers type)". This design "Recommended design" is suitable to be implemented in arid areas based on the properties of weather parameters that are available in these areas (high temperature, and a low rainfall amount but with high intensity in short duration).

Generally, the suggested design of landfill has achieved its main objective in Babylon Governorate, and this design can be applied in similar arid areas in Iraq.

\section{Acknowledgments}

Ali Chabuk (The first author) has a scholarship from University of Babylon, Iraq through the Iraqi Ministry of Higher Education \& Scientific Research, to do his PhD degree at Lulea University of Technology (LTU). Lulea University of Technology provided all facilities.

\section{References}

[1] Brockerhoff, M. 2000. "An Urbanizing World." Population Reference Bureau 55 (3): 48.

[2] Proske, H., Vlcko, J., Rosenbaum, M. S., Dorn, M., Culshaw, M., and Marker, B. 2005. "Special Purpose Mapping for Waste Disposal Sites." Bulletin of Engineering Geology and the Environment 64 (1): 1-54.

[3] Moeinaddini, M., Khorasani, N., Danehkar, A., and Darvishsefat, A. A. 2010. "Siting MSW landfill using Weighted Linear Combination and Analytical Hierarchy Process (AHP) Methodology in GIS Environment (Case Study: Karaj)." Waste Management 30 (5): 912-20.

[4] Alslaibi, T. M., Abustan, I., Mogheir, Y. K., and Afifi, S. 2013. "Quantification of Leachate Discharged to Groundwater Using the Water Balance Method and the Hydrologic Evaluation of Landfill Performance (HELP) model." Waste Management \& Research 31 (1): 50-9.

[5] Joseph, K., Nagendran, R., Palanivelu, K., Thanasekaran, K., and Visvanathan, C. 2004. "Dumpsite Rehabilitation and Landfill Mining.” CES, Anna University, Chennai, India under ARRPET. Accessed October 5, 2017. http://saahas.org/wpcontent-saahas/uploads/2015/02/Land fills3.pdf.

[6] Renou, S., Givaudan, J. G., Poulain, S., Dirassouyan, F., and Moulin, P. 2008. "Landfill Leachate Treatment: Review and Opportunity." Journal of Hazardous Materials 150 (3): 468-93.

[7] Scott, J., Beydoun, D., Amal, R., Low, G., and Cattle, J. 2005. "Landfill Management, Leachate Generation, and Leach Testing of Solid Wastes in Australia and Overseas." Critical Reviews in Environmental Science and Technology 35 (3): 239-332.

[8] Munawar, E., and Fellner, J. 2013. "Guidelines for Design and Operation of Municipal Solid Waste Landfills in Tropical Climates." ISWA-the International Solid Waste Association, Technische Universität Wien, Vienna.

[9] Hughes, K. L., Christy, A. D., and Heimlich, J. E. 2007. "Landfill Types and Liner Systems." Ohio State University Extension Fact Sheet CDFS-138.

[10] U.S. Department of Energy. 2000. "Alternative Landfill Cover." Subsurface Contaminants Focus Area and Characterization, Monitoring, and Sensor Technology Crosscutting Program. Office of Environmental Management Office of Science and Technology, Sandia National Laboratories Sandia, New Mexico. Accessed July 2, 2017. https://www.flagstaff.az.gov/Document Center/View/11018/USDOE-2000?bidId=.

[11] Iraqi Ministry of Water Resources. 2015. General Commission for Groundwater. Internal Reports, Iraqi Ministry of Water Resources, Baghdad, Iraq.

[12] Berger, K. U. 2015. "On the Current State of the Hydrologic Evaluation of Landfill Performance (HELP) Model." Waste Management 38: 201-9.

[13] Berger, K. U., and Schroeder, P. R. 2013. "The Hydrologic Evaluation of Landfill Performance (HELP) Model." User's guide for HELP-D (version 3.95 D)." 6th revised edition for version HELP 3.95D. Institute of Soil Science, University of Hamburg, Germany.

[14] Schroeder, P. R., Dozier, T. S., Zappi, P. A., McEnroe, B. M., Sjostrom, J. W., and Peyton, R. L. 1994. "The Hydrologic Evaluation of Landfill Performance (HELP) Model: Engineering Documentation for Version 3." U.S. Environmental Protection Agency Office of Research and Development, Washington, DC, USA.

[15] Chabuk, A., Al-Ansari, N., Alkaradaghi, K., Al-Rawabdeh, A., Laue, J., Hussain, H.M., Pusch, R., and Knutsson, S. 2018. "Landfill Final Cover Systems Design for Arid Areas Using the HELP Model: A Case Study in the Babylon Governorate, Iraq." Sustainability 10 (12): 4568.

[16] Chabuk, A., Al-Ansari, N., Ezz-Aldeen, M., Laue, J., Pusch, R., Hussain, H. M., and Knutsson, S. 2018. "Two 
Scenarios for Landfills Design in Special Conditions Using the HELP Model: A Case Study in Babylon Governorate, Iraq.” Sustainability 10 (125): 1-26.

[17] Alslaibi, T. M., Mogheir, Y. K., and Afifi, S. 2010. "Analysis of Landfill Components in Estimating the Percolated Leachate to Groundwater Using the HELP Model." Water Science and Technology 62 (8): 1727-34.

[18] Al-Taie, L. 2014. "Performance of Clay Liners in Near-Surface Repositories in Desert Climate." Ph.D. thesis, Soil Mechanics and Foundation Engineering, Lulea University of Technology, Lulea, Sweden.

[19] Frikha, Y., Fellner, J. and Zairi, M. 2017. "Leachate Generation from Landfill in a Semi-arid Climate: A Qualitative and Quantitative Study from Sousse, Tunisia." Waste Management \& Research 35: 940-8.

[20] EPA Victoria (Environment Protection Authority Victoria). 2015. Variation to the Best Practice Environmental Management-Siting, Design, Operation and Rehabilitation of Landfills. EPA Victoria Publication, published in the Victorian Government Gazette.

[21] SCIPEG (SCIP Engineering Group). 2014. Conceptual Design of a New Waste Disposal Facility for Lesedi Local Municipality, Heidelberg. Report No. (10612452-12628-7), Golder Associates: Mississauga, USA.

[22] Al-Yaqout, A., and Townsend, F. 2001. "Strategy for Landfill Design in Arid Regions." Practice Periodical of Hazardous, Toxic, and Radioactive Waste Management 5 (1): 2-13.

[23] Abu-Rizaiza, A. S., and Abdul Aziz, H. 2011. "The Proposed Design and Tendering for the New Phase of Landfill at Southern Makkah Disposal Site: Phase 1, Design Report." Collaborative Consultation Project between King Abdulaziz University: Jeddah, Saudi Arabia; Universiti Sains Malaysia: Penang, Malaysia.

[24] Ireland EPA (Ireland Environmental Protection Agency). 2000. Landfill Manuals Landfill Site Design. Wexford, Ireland: Environmental Protection Agency.

[25] British Columbia. 2016. Landfill Criteria for Municipal Solid Waste (2nd ed.). British Columbia, Canada: Ministry of Environment.

[26] Al Khalidy, K. S., Chabuk, A. J., and Kadhim, M. M. 2012. "Measurement of Lead Pollution in the Air of Babylon Governorate, Iraq during Year 2010." World Academy of Science, Engineering and Technology 6: 830-3.

[27] Inter-Agency Information and Analysis Unit, and United Nations Office for the Coordination of Humanitarian Affairs. 2009. Babil Governorate Profile, Iraq. Accessed June 20, 2018. https://reliefweb.int/sites/reliefweb.int/ files/resources/281B2917F8944AF4C12576120035A444 -Full_Report.pdf.
[28] Iraqi Ministry of Municipalities and Public Works. 2009. "Structural Plan of Babylon Governorate." The Directorate General of Urban Planning, Information Analysis Report (Revised); Stage 2, Iraqi Ministry of Municipalities and Public Works: Baghdad, Iraq.

[29] Iraqi Ministry of Planning. 2017. Records of Directorate of Census Babylon. Internal Reports, Babylon, Iraqi Ministry of Planning, Baghdad, Iraq.

[30] Jaradat, A. A. 2002. "Agriculture in Iraq: Resources, Potentials, Constraints, and Research Needs and Priorities." Department of State-Middle East Working Group on Agriculture, Washington, D. C., USA.

[31] FAO. 2003. "Towards Sustainable Agricultural Development in Iraq." The Transition from Relief, Rehabilitation and Reconstruction to Development.

[32] Frenken, K. 2009. "Irrigation in the Middle East Region in Figures, AQUASTAT Survey-2008." Food and Agriculture Organization of the United Nations (FAO), FAO Water Reports (34), Rome, Italy.

[33] Kadhim, A. J. 2011. "Climate Classification of the Kifil Area South Babylon Governorate/Iraq." Euphrates Journal of Agriculture Science 3 (9): 115-22. (Special issue for the First International Conference Iraq/Iran). Accessed June $10, \quad 2018$. https://www.iasj.net/iasj?func=fulltext\&aId $=49278$.

[34] CEB (Consulting Engineering Bureau College of Engineering). 2012. Hydrological Study of Ancient Babylon Site. Final Internal Report, Iraqi Ministry of Higher Education \& Scientific Research, Baghdad University, Baghdad, Iraq.

[35] Iraqi Ministry of Transportation Constitutions. 2017. Iraqi Meteorological Organization \& Seismology. Internal Reports, Iraqi Ministry of Transportation constitutions, Baghdad, Iraq.

[36] Jarabi, B. 2015. "Population Projections, Population Studies \& Research Institute." University of Nairobi. Accessed on January 6, 2015. http://unstats.un.org/unsd/demographic/meetings/wshops/ morocco/2012/do-cs/s02.ppt.

[37] Iraqi Ministry of Municipalities and Public Works. 2013a. Records of Directorate of Babylon Municipalities, Babylon. Internal reports, Iraqi Ministry of Municipalities and Public Works, Baghdad, Iraq.

[38] Iraqi Ministry of Municipalities and Public Works. 2013b. Records of Directorate of Al-Hillah Municipality. Internal reports, Iraqi Ministry of Municipalities and Public Works, Baghdad, Iraq.

[39] Al-Rawe, S. M., and AL-Tayyar, T. A. 2012. "Two Decades Comparison of Solid Waste Composition and Generation in Mosul City." Tikrit Journal of Engineering Sciences 19 (1): 25-43.

[40] Oweis, I. S., and Khera, R. P. 1998. Geotechnology of 
Waste Management (2nd ed.). Boston, MA, USA: PWS Publishing Company.

[41] Vesilind, P. A., Worrell, W., and Reinhart, D. 2002. Solid Waste Engineering. Philadelphia, PA, USA: Brooks/Cole; Pacific Grove.

[42] UNEP-IETC. 2006. "International Source Book on Environmentally Sound Technologies (ESTs) for Municipal Solid Waste Management (MSWM).” United Nations Environment Programme, Division of Technology, Industry and Economics. Accessed February 20, 2017. http://www.unep.or.jp/Ietc/ESTdir/Pub/ MSW/index.asp.

[43] Jassim, S. Z., and Goff, J. C. 2006. "Geology of Iraq." DOLIN, sro, distributed by Geological Society of London.

[44] Chabuk, A., Al-Ansari, N., Hussain, H. M., Knutsson, S., Pusch, R., and Laue, J. 2017b. "Landfills Site Selection in Babylon, Iraq." Journal of Earth Sciences and Geotechnical Engineering 7 (4): 1-15.

[45] Iraqi Ministry of Education. 2015. Data of the Directorate General. Internal reports, Iraqi Ministry of Education, The Department of Scientific Affairs, Baghdad, Iraq.

[46] Buringh, P. 1960. "Soils and Soil Conditions in Iraq." Ministry of Agriculture.

[47] Iraqi Ministry of Water Resources. 1990. State Commission of Survey. Internal reports, Iraqi Ministry of Water Resources, Baghdad, Iraq.

[48] World Digital Library. 2013. "The Archaeological Map of Iraq." Accessed on September 24, 2015. http://www.wdl.org/en/item/212/.

[49] Iraqi Ministry of Oil. 2015. Limitations of Oil and Gas Pipelines Law No. 40145 in 1989, Oil Pipelines Company. Internal reports, Iraqi Ministry of Oil, Baghdad, Iraq.

[50] Chabuk, A., Al-Ansari, N., Hussain, H. M., Knutsson, S., and Pusch, R. 2016. "Landfill Site Selection Using Geographic Information System and Analytical Hierarchy Process: A Case Study Al-Hillah Qadhaa, Babylon, Iraq." Waste Management \& Research 34 (5): 427-37.

[51] Chabuk, A. J., Al-Ansari, N., Hussain, H. M., Knutsson, S., and Pusch, R. 2017a. "GIS-based Assessment of Combined AHP and SAW Methods for Selecting Suitable Sites for Landfill in Al-Musayiab Qadhaa, Babylon, Iraq." Environmental Earth Sciences 76 (5): 209-20.

[52] Chabuk, A., Al-Ansari, N., Hussain, H. M., Knutsson, S., Pusch, R., and Laue, J. 2017b. "Landfill Sitting by Two Methods in Al-Qasim, Babylon, Iraq and Comparing Them Using Change Detection Method." Engineering 9 (8): 723-37.

[53] Chabuk, A., Al-Ansari, N., Hussain, H. M., Knutsson, S., and Pusch, R. 2017c. "Landfill Sites Selection Using Analytical Hierarchy Process and Ratio Scale Weighting: Case Study of Al-Mahawil, Babylon, Iraq." Engineering 9 (2): $123-41$.
[54] Chabuk, A., Al-Ansari, N., Hussain, H. M., Knutsson, S., Pusch, R., and Laue, J. 2017. "Combining GIS Applications and Method of Multi-Criteria Decision-Making (AHP) for Landfill Siting in Al-Hashimiyah Qadhaa, Babylon, Iraq.” Sustainability 9 (11): 123-41.

[55] Iraqi Ministry of Housing \& Construction. 2016. National Center for Construction Laboratories and Research. Internal report, Iraqi Ministry of Housing \& Construction, Baghdad, Iraq.

[56] Chabuk, A., Al-Ansari, N., Hussain, H. M., Kamaleddin, S., Knutsson, S., Pusch, R., and Laue, J. 2017e. "Soil Characteristics in Selected Landfill Sites in the Babylon Governorate, Iraq." Journal of Civil Engineering and Architecture 11 (4): 348-63.

[57] Chabuk, A., Al-Ansari, N., Hussain, H. M., Knutsson, S., and Pusch, R. 2015. "Present Status of Solid Waste Management at Babylon Governorate, Iraq." Engineering 5 (7): 408-23.

[58] NSW EPA (New South Wales Environment Protection Authority). 2016. Environmental Guidelines: Solid waste landfills (2nd ed.). Sydney: New South Wales Environment Protection Authority.

[59] Bagchi, A. 2004. Design of Landfills and Integrated Solid Waste Management (3rd ed.). Hoboken, NJ: John Wiley \& Sons, Inc.

[60] Joyal, C. 2006. New Solid Waste Facility-Preliminary Design Report. Final report, Department of Public Works and Engineering, Dillon Consulting Limited, Yellowknife, NT, Canada.

[61] SIGIR (Special Inspector General for Iraq Reconstructive). 2006. Baghdad Municipal Solid Waste, Memorandum for Commanding General, Multi-National Forces-Iraq. Report on Project Assessment of the Baghdad Municipal Solid Waste Landfill, Baghdad, Iraq.

[62] Swedish EPA (Swedish Environmental Protection Agency). 2004. Landfilling of Waste, Handbook with General Advice to the Ordinance (SFS 2001:512) on Disposal of Waste and to Chapter 15, § 34 in the Environmental Code (SFS 1998:808). Swedish Environmental Protection Agency Handbook: Stockholm, Sweden.

[63] Rowe, R. K., and Sangam, H. P. 2002. "Durability of HDPE Geomembranes." Geotextiles and Geomembranes 20 (2): 77-95.

[64] Ramke, H. G. 2001. "Appropriate Design and Operation of Sanitary Landfills.” Paper presented on International Conference on Sustainable Economic Development and Sound Resource Management in Central Asia, Tashkent, Uzbekistan.

[65] JICA (Japan International Cooperation Agency). 2004. "The Study on the Safe Closure and Rehabilitation of 
Landfill Sites in Malaysia." In Technical Guideline for Sanitary Landfill, Design and Operation, Revised Draft; Final Report; Japan International Cooperation Agency, Yachiyo Engineering Co., Ltd., EX Corporation, Tokyo, Japan.

[66] Rong, L. 2009. "Management of Landfill Leachate.” Ph.D. thesis, Degree Programme of Environmental Engineering, TAMK University of Applied Sciences, Finland.

[67] Oni, O. A. 2000. "An Investigation into the Impact of Sequential Filling on Properties of Emplaced Refuse Lifts and Moisture Stored in a Municipal Solid Waste Landfill." Doctoral dissertation, University of Southampton, UK.

[68] Madalinski, K. L., Gratton, D. N., and Weisman, R. J. 2003. "Evapotranspiration Covers: An Innovative Approach to Remediate and Close Contaminated Sites." Remediation Journal: The Journal of Environmental Cleanup Costs, Technologies \& Techniques 14 (1): 55-67.

[69] Laue, J., Nater, P., and Herzog, R. 2003. "Soil Structure Interaction of Circular Footings on Layered Soil: First Results." In Proceedings of the International Conference BGA International Conference on Foundations: Innovations, Observations, Design and Practice, 463-72.

[70] Structural Engineering Resources (STRUCT). Accessed April 10, 2017. https://structx.com/Soil_Properties 002.html.

[71] DeHavilland, A. 2004. "Geotechnical and Stability Analyses for Ohio Waste Containment Facilities." Ohio Environmental Protection Agency Geotechnical Resource Group. Columbus, Ohio.

[72] Geotech data info. 2013. "Typical Values of Soil Void Ratio for Different Soils.” Accessed August 10, 2018. http://www.geotechdata.info/parameter/void-ratio.html.

[73] Widodo, S., and Ibrahim, A. 2012. "Estimation of Primary Compression Index (CC) Using Physical Properties of Pontianak Soft Clay." International Journal of Engineering Research and Applications (IJERA) 2: 2232-6.

[74] Jaramillo, J. 2003. "Guidelines for the Design, Construction and Operation of Manual Sanitary Landfills." Pan American Center for Sanitary Engineering and Environmental Science.

[75] NewFields (New Fields Mining Design \& Technical Services). 2015. "Run-on and Run-off Control Plan CCR Landfill, TS Power Plant Eureka County, Nevada." 1301 N. McCarran Blvd., Suite 101 Sparks, Nevada 89431. Prepared for: TS Power Plant, 914 Dunphy Ranch Road Battle Mountain, Nevada 89820.

[76] Hull and Associates INC. 2016. "Run-on and Run-off Control System Plan." Southwestern Electric Power Company, Flint Creek Power Plant Landfill, Toledo, Ohio. Accessed June 17, 2018. https://www.aep.com/Assets/docs/requiredpostings/ccr/2
016/InitialRun-onandRun-offControlPlans/FC-LF-Runon Runoff-101616.pdf.

[77] Greedy, D., Kocasoy, G., Mavropoulos, A., Thrane, J., Ossai, R., Nagar, B., de Bord, W., Hamilton, S., de Bastos, D., Bergman, H., and Kortegast, T. 2010. Landfill Operational Guidelines (2nd ed.). ISWA Working Group on Landfill.

[78] GFL (Green For life) Environmental Inc. 2018. Landfill Design and Operations Existing Conditions Report. Eastern Ontario Waste Handling Facility Landfill Expansion Environmental Assessment. Moose Creek, Ontario, Canada. Prepared by Tetra Tech, Boucherville, QC J4B 7M6, Canada.

[79] Manitoba Sustainable Development. 2016. "Leachate Management at a Waste Management Facility." Manitoba.ca, Sustainable Development, Environmental Compliance and Enforcement. Accessed October 5, 2017. https://www.gov.mb.ca/sd/-envprograms/swm/pdf/leachat e_management_wdg.pdf.

[80] Callander, I. J., and Barford, J. P. 1983. "Precipitation, Chelation, and the Availability of Metals as Nutrients in Anaerobic Digestion. II. Applications.” Biotechnology and Bioengineering 25 (8): 1959-72.

[81] Pacific Regional Environment Programme. 2005. “A Practical Guide to Landfill Management in Pacific Island Countries." Volume-1, Inland-based Waste Disposal.

[82] U.S. EPA. 2012. "International Best Practices Guide for Landfill Gas Energy Projects." The United States Environmental Protection Agency (EPA) and International Solid Waste Association (ISWA). Global Methane Initiative. Accessed September 5, 2018. https://www.globalmethane.org/documents/toolsres_lfg_i bpgcomplete.pdf.

[83] Cooper, D. 2017. "How to Plan and Design a Landfill Gas Collection System.” MSW Management Weekly, 3.

[84] Guidance on Landfill Gas Control. 2013. "Landfill Gas Control-Guidance on the Landfill Gas Control Requirements of the Landfill Directive." Landfill Waste-Environment-European Commission. Accessed September 5, 2018. http://ec.europa.eu/environment/ waste/landfill_index.htm.

[85] Bauerle, M. 2016. "Adapting the Hydrologic Evaluation of Landfill Performance (HELP) Model to the Climatic and Soil Characteristics of Queensland.” Doctoral dissertation, Queensland University of Technology, Brisbane, Australia.

[86] Fellner, J. 2011. "Landfilling in Iraq From Open dumping to Sanitary Landfills." UN-HABITAT for a better future, Iraq waste management, Vienna University of Technology (TU WIEN), International Solid Waste Association (ISWA).

[87] McEnroe, B. M. 1993. "Maximum Saturated Depth over 


\section{Babylon Governorate, Iraq}

Landfill Liner." Journal of Environmental Engineering 119 (2): 262-70.
[88] Pusch R. 2008. Geological Storage of Highly Radioactive Waste. Verlag Berlin Heidelberg: Springer. 